\title{
Integrated Campaign for Aerosols, gases and Radiation Budget (ICARB): An overview
}

\author{
K Krishna Moorthy ${ }^{1}$, S K Satheesh ${ }^{2}$, S Suresh Babu ${ }^{1}$ and C B S Dutt ${ }^{3}$ \\ ${ }^{1}$ Space Physics Laboratory, Vikram Sarabhai Space Centre, Trivandrum 695 022, India. \\ ${ }^{2}$ Centre for Atmospheric and Oceanic Sciences, Indian Institute of Science, Bangalore 560 012, India. \\ ${ }^{3}$ Indian Space Research Organisation Head Quarters, New BEL Road, Bangalore 560 094, India.
}

During March-May 2006, an extensive, multi-institution, multi-instrument, and multi-platform integrated field experiment 'Integrated Campaign for Aerosols, gases and Radiation Budget' (ICARB) was carried out under the Geosphere Biosphere Programme of the Indian Space Research Organization (ISRO-GBP). The objective of this largest and most exhaustive field campaign, ever conducted in the Indian region, was to characterize the physico-chemical properties and radiative effects of atmospheric aerosols and trace gases over the Indian landmass and the adjoining oceanic regions of the Arabian Sea, northern Indian Ocean, and Bay of Bengal through intensive, simultaneous observations. A network of ground-based observatories (over the mainland and islands), a dedicated ship cruise over the oceanic regions using a fully equipped research vessel, the Sagar Kanya, and altitude profiling over selected regions using an instrumented aircraft and balloonsondes formed the three segments of this integrated experiment, which were carried out in tandem. This paper presents an overview of the ICARB field experiment, the database generated, and some of its interesting outcomes though these are preliminary in nature.

The ICARB has revealed significant spatio-temporal heterogeneity in most of the aerosol characteristics both over land and ocean. Observed aerosol loading and optical depths were comparable to or in certain regions, a little lower than those reported in some of the earlier campaigns for these regions. The preliminary results indicate:

- low $(<0.2)$ aerosol optical depths (AOD) over most part of the Arabian Sea, except two pockets; one off Mangalore and the other, less intense, in the central Arabian Sea at $\sim 18^{\circ} \mathrm{N}$ latitude;

- High Ångström exponent in the southern Arabian Sea signifying steep AOD spectra and higher abundance of accumulation mode particles in the southern Arabian Sea and off Mangalore;

- Remarkably low Ångström exponents signifying increased concentration of coarse mode aerosols and high columnar abundance in the northern Arabian Sea;

- Altitude profiles from aircraft showed a steady BC level up to $3 \mathrm{~km}$ altitude with structures which were associated with inversions in the atmospheric boundary layer (ABL);

- A surprisingly large increase in the BC mass fraction with altitude;

- Presence of a convectively mixed layer extending up to about $1 \mathrm{~km}$ over the Arabian Sea and Bay of Bengal;

- A spatial off shore extent of $<100 \mathrm{~km}$ for the anthropogenic impact at the coast; and

- Advection of aerosols, through airmass trajectories, from west Asia and NW arid regions of India leading to formation of elevated aerosol layers extending as far as $400 \mathrm{~km}$ off the east coast.

Keywords. ICARB, atmospheric aerosols; radiative forcing; Bay of Bengal and Arabian Sea aerosols; altitude profiles; Micro Pulse Lidar. 


\section{Introduction}

Atmospheric aerosols play an important role in the Earth's energy budget and contribute to climate change. They affect the climate directly by scattering and absorbing radiation (McCormick and Ludwig 1967; Charlson et al 1992) and indirectly by acting as cloud condensation nuclei and thereby affecting cloud properties (Twomey 1977). However, radiative forcing and the resulting climate impact due to atmospheric aerosols remain largely uncertain primarily due to inadequate data representing the spatio-temporal heterogeneity of the aerosol properties and in the understanding of aerosol cloud interactions (IPCC 2007). The uncertainty in the aerosol direct climate forcing is estimated to be in the range of -0.1 to $-0.9 \mathrm{~W} \mathrm{~m}^{-2}$ (with a mean value of $-0.5 \mathrm{~W} \mathrm{~m}^{-2}$ ), while it is much higher for the indirect forcing (varying from -0.3 to $-1.8 \mathrm{~W} \mathrm{~m}^{-2}$ ) with a mean value of $-0.7 \mathrm{~W} \mathrm{~m}^{-2}$. Reduction of these uncertainties calls for a co-ordinated research strategy that will successfully integrate data from multiple platforms such as ground-based network, ship, aircraft, balloon, and satellite, as well as numerical modeling and data assimilation (Penner et al 1994; Kaufman et al 2002; Diner et al 2004; Yu et al 2006). This is particularly needed for the Asian region, with all its natural diversities, high density of population, diverse living habits, and the growing industrialization and urbanization.

Over the past decade, more than a dozen intense field experiments have been conducted to characterize physical, chemical, and optical properties, and the radiative effects of aerosols in a variety of aerosol regimes around the world. These include BASE-A over Brazil (Kaufman et al 1992), SAFARI-92 over the southern Atlantic and southern Africa (Lindesay et al 1996), TRACE-A over the southern Atlantic (Fishman et al 1996), SCAR-A over North America (Remer et al 1997), SCAR-B over Brazil (Kaufman et al 1998), ACE-1 over the Southern Oceans (Bates et al 1998), TARFOX over the northwestern Atlantic (Russell et al 1999), ACE-2 over the northern Atlantic (Raes et al 2000), Aerosols99 over the Atlantic (Bates et al 2001), INDOEX over the Indian Ocean (Ramanathan et al 2001), SAFARI-2000 over South Africa and the south Atlantic (King et al 2003), PRIDE over Puerto Rico (Reid et al 2003), TRACE-P over east Asia and the northwestern Pacific (Jacob et al 2003), ACE-Asia over east Asia and the northwest Pacific (Huebert et al 2003), MINOS over the Mediterranean region (Lelieveld et al 2002), CLAMS over the east coast of U.S. (Smith et al 2005) and NEAQS over the north Atlantic (Quinn and Bates 2005). During each of these comprehensive missions, aerosols were studied in great detail, using combinations of in situ and remote sensing observations of physical and chemical properties from different platforms. In addition, long term aerosol monitoring network such as AERONET of NASA (Holben et al 1998), sunphotometer network in east Asia (SKYNET, http://atmos.cr.chibau.ac.jp/aerosol/skynet), multifilter shadowband radiometer (MFRSR) network in north America (Alaxandrov et al 2002), Micropulse Lidar Network (MPLNET) of NASA (Welton et al 2001), and European Aerosol Research Lidar Network (Matthias et al 2004) were pursued, essentially to understand the complex physical and optical properties of atmospheric aerosols.

Despite the large diversities in aerosol characteristics over India, a concerted effort leading to development of region-specific and seasonspecific aerosol models remains to be achieved. The Geosphere Biosphere Programme of the Indian Space Research Organization (ISRO-GBP) however, has been addressing this problem in a focused manner using a chain of ground-based observatories over the mainland and islands in the Arabian Sea (AS) and Bay of Bengal (BoB) (now called the ARFI network, ARFI standing for Aerosol Radiative Forcing over India), supplemented with pilot campaigns (for e.g., Moorthy et al 2005a, b; Ganguly et al 2005; Vinoj et al 2004; Tripathi et al 2005; Pant et al 2006; Babu et al 2002, 2004). Based on the inferences drawn from such efforts, an integrated campaign, the first of its kind over this region, was conceived and executed during the March-May period of 2006. This campaign, ICARB (Integrated Campaign for Aerosols, gases, and Radiation Budget), is also the first of a series of such campaigns planned under ISRO-GBP. Brief descriptions of the campaign concept and details of its execution are given in the following sections with some preliminary results.

\section{Scientific objectives and measurements}

The ICARB essentially addressed the following issues:

- What is the nature of the spatio-temporal heterogeneities of the aerosol environment over India and the adjoining oceans? Where are the hotspots (natural/anthropogenic) and sinks? How does the spatial distribution change with time?

- What is the nature of the vertical distribution of aerosol properties over the coastal regions which interface between the more polluted continental regions and the less polluted oceanic regions? 
How strong are the elevated aerosol layers at different regions?

- What are the influences of long-range transport and regional meteorology on the spatial distribution of aerosols and gases? How strong are the impacts of advection from different source regions in India, south China, east Asia, etc., over the BoB and India, west Asia, and Africa over the Arabian Sea? How does the change in the prevailing circulation pattern modify the regional distribution?

- What is the net impact of aerosols on regional radiative forcing and how does this forcing change with the above processes?

- What are the impacts of mesoscale processes like the land/sea-breeze activity on the surface concentrations and altitude profiles of aerosols along the coastal regions? What is the spatial variation of marine atmospheric boundary layer (MABL) over the BoB and Arabian Sea and what are its implications to vertical and horizontal exchanges?

In order to address the above questions, the following parameters pertaining to aerosols and gases were measured or estimated using collocated measurements during ICARB:

- Spectral Aerosol Optical Depth, AOD (over the land network, onboard the ship and from Minicoy and Port Blair islands).

- Mass concentration and size distribution of composite aerosols over the land and ocean.

- Bulk aerosol sampling from coastal, inland and oceanic environments for identifying and distinguishing major chemical species as well as to assess the source strength of different geographical regions using the chemical composition as fingerprints.

- Mass concentrations of aerosol black carbon over selected land stations, islands, and onboard the cruise and aircraft.

- Balloon and SODAR measurements of boundary layer parameters to understand the vertical mixing in the marine atmospheric boundary layer over the oceans.

- GPS-sonde measurements of the altitude profiles of ozone over the oceanic regions.

- Altitude profiles of aerosol extinction using micro-pulse lidar (MPL) onboard the aircraft supplemented with similar measurements from the adjoining coastal mainland in conjunction with the cruise measurements.

- Aircraft measurements of vertical profiles of important aerosol species and trace gases over the study area and horizontal gradients to understand the spatial dispersion of these species and to model them.

\section{Period of the campaign}

The campaign, spanning for about two months, was conducted in the window March to May 2006. The main rationales in selecting the campaign window were:

- Availability of uninterrupted sunshine over the entire region (India and adjoining continents as well as over the oceanic region) for most of the time.

- The period forms part of the long, Asian dry season, with very little precipitation and hence the aerosols have long atmospheric residence time even in the lower troposphere.

- The period also favours a significant amount of long-range "trans-boundary transport" of aerosols and trace gases from central India, east and southeast Asia to the BoB and west Asia and east Africa, as well as India to the Arabian Sea (Moorthy et al 2003, 2005a).

\section{The structure of ICARB}

The campaign was structured following an 'integrated-segmented' approach. It consisted of three observation-intense segments; viz., the land segment, the ocean segment, and the air segment. Each segment was planned to be self-contained and complete, the data from all these will be synthesized to characterize the spatio-temporal features, which would then be used for regional radiative forcing.

\subsection{The land segment}

The land segment comprised fixed aerosol observatories, making continuous time series measurements of several aerosol parameters following a common protocol. These observatories are spread over the Indian mainland as shown by the circles encircling the star symbols in figure 1, as well as two island observatories, Minicoy (MCY) in the $\mathrm{AS}$ and Port Blair (PBR) in the BoB. Here the observations are carried out on a continuous basis. In all, there were 18 stations operating in the network. The stations and the measurements from these are listed in table 1.

\subsection{The ocean segment}

The ocean segment of ICARB was designed so as to obtain a snapshot of various parameters of aerosols and gases (that are important in estimating the radiative forcing), using collocated instruments, operating as far as possible, under the same environmental conditions, covering the vast 


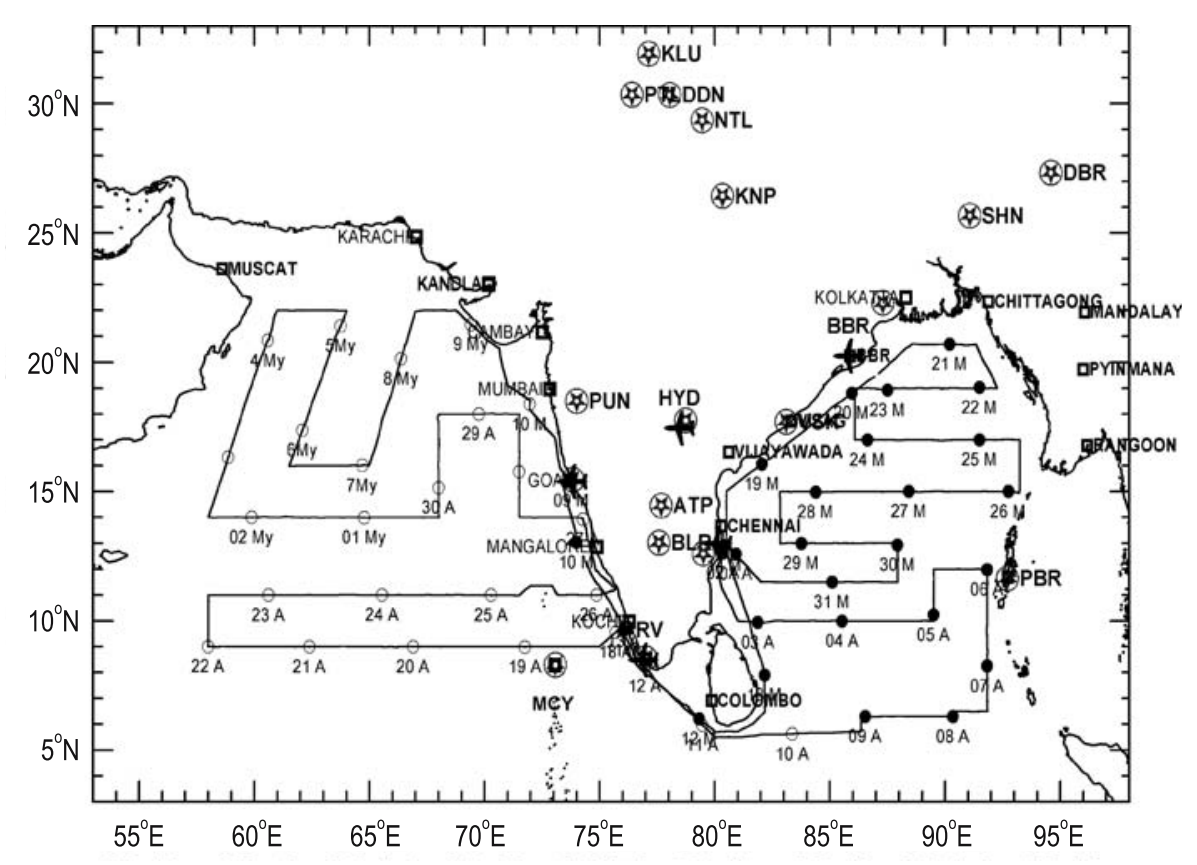

Figure 1. Schematic representation of the operational phase of ICARB during March-May 2006. The continuous lines show the cruise track of SK223 (in the ocean segment). The points on the lines indicate the ship's location at 05:30 UTC for the date identified below it; the number stands for the day and the alphabet for the month, M for March, A for April, and My for May. The bases from where the aircraft sorties were made are identified with a symbol of the aircraft. The other points represent the fixed stations of the land segment, from where aerosol and gas measurements were made.

oceanic regions of the BoB, northern Indian Ocean (IO), and the AS, during a climatologically distinct season when the prevailing conditions do not change drastically. As such, measurements of all the relevant parameters were carried out onboard the oceanographic research vessel $(O R V)$ Sagar Kanya, of the Department of Ocean Development, the cruise\# SK223, which was dedicated to the ICARB, to cover the entire oceanic regions of interest in as short a time-span as possible. This would provide a statistically stationary (in temporal scale) spatial mosaic of all the parameters with a reasonable spatial resolution needed for inputting to the current General Circulation Models (GCM) for climate impact assessment. Moreover, the climatological winds over these regions and their relevance to transport aerosols to different oceanic regions, and the extent of cloudiness were also considered. The cruise had two main legs; SK223A covering the BoB and northern IO regions, and 223B covering the Arabian Sea. There was a short cruise for a period of one week, preceding SK223A, which was considered as a dry run, and during this some of the aerosol instruments were set up, fine tuned and calibrated. Several measurements were also initiated in this phase. Details are given in table 2, while the tracks are shown in figure 1 by the lines over the oceanic regions. Overall the ship sailed for 56 days during ICARB, covering a track length of $>25,000 \mathrm{~km}$ surveying the atmosphere over an oceanic area $>4$ million $\mathrm{km}^{2}$. Important urban conglomerations and ports on the mainland, en route the cruise, are marked in figure 1 , so that the rationale of the track would be easily understood. During its course, the cruise collected atmospheric data from coastal regions adjacent to major urban centres such as Goa, Mangalore, Kochi, Chennai, Nellore, Vijayawada, Visakhapatnam, Bhubaneswar/Puri, Kolkata, Chittagong, Ranagoon, Port Blair, Colombo (and southern Sri Lanka), Trivandrum, Lakshadweep, Mumbai, Kutch, Kandla and the eastern coasts of Oman, Yemen and Muscat and put these data in juxtaposition with those from far and pristine oceanic environments of the $\mathrm{BoB}$ and Arabian Sea.

In the ocean segment collocated measurements of more than 20 parameters of aerosols and trace gases, data on the state of the atmosphere (including the marine atmospheric boundary layer, MABL), and vertical profiles of meteorological parameters and concentration of ozone, were made using about 40 different instruments by a team from 26 national laboratories, academic institutions, and universities, onboard the ORV. For aerosols and gas measurements, two dedicated laboratories were set up in the top (B and $\mathrm{C}$ ) decks of the ORV, with community air inlets providing the air samples needed for all the indoor measuring instruments (figure 2, top). All the outdoor 
Table 1. Ground network stations and measurements.

\begin{tabular}{|c|c|c|c|}
\hline Station & Location & Parameters measured & Instruments used \\
\hline Minicoy & $8.2^{\circ} \mathrm{N}, 73.0^{\circ} \mathrm{E}, 1 \mathrm{~m}$ & $\mathrm{AOD}, \mathrm{NSD}, M_{B}$ & $\begin{array}{l}\text { MWR, MTPS, } \\
\text { OPC, Aethalometer }\end{array}$ \\
\hline Trivandrum & $8.55^{\circ} \mathrm{N}, 77^{\circ} \mathrm{E}, 3 \mathrm{~m}$ & $\mathrm{AOD}, \mathrm{NSD}, M_{B}$ & $\begin{array}{l}\text { MWR, ELPI, } \\
\text { Aethalometer }\end{array}$ \\
\hline Bangalore & $13^{\circ} \mathrm{N}, 77^{\circ} \mathrm{E}, 960 \mathrm{~m}$ & $\mathrm{AOD}$ & MWR \\
\hline Anantapur & $14.7^{\circ} \mathrm{N}, 77.6^{\circ} \mathrm{E}, 331 \mathrm{~m}$ & AOD & MWR \\
\hline Kalpakkam & $12.56^{\circ} \mathrm{N}, 80.17^{\circ} \mathrm{E}, 12 \mathrm{~m}$ & AOD, $M_{B}$, Scatt coeff & $\begin{array}{l}\text { MTPS, Aethalometer, } \\
\text { Nephelometer }\end{array}$ \\
\hline Port Blair & $11.63^{\circ} \mathrm{N}, 92.7^{\circ} \mathrm{N}, 73 \mathrm{~m}$ & $\mathrm{AOD}, M_{T}, \mathrm{MSD}, M_{B}$ & $\begin{array}{l}\text { MWR, QCM, } \\
\text { Aethalometer }\end{array}$ \\
\hline Visakhapatnam & $17.7^{\circ} \mathrm{N}, 83.3^{\circ} \mathrm{E}, 5 \mathrm{~m}$ & $\begin{array}{l}\text { AOD, EXTN } \\
\text { PROFILE }\end{array}$ & MWR, MPL \\
\hline Hyderabad & $17.48^{\circ} \mathrm{N}, 78.4^{\circ} \mathrm{E}, 545 \mathrm{~m}$ & $\mathrm{AOD}, M_{B}$ & MWR, Aethalometer \\
\hline Pune & $18.72^{\circ} \mathrm{N}, 73.85^{\circ} \mathrm{E}, 559 \mathrm{~m}$ & $M_{B}$ & Aethalometer \\
\hline New Delhi & $28.6^{\circ} \mathrm{N}, 77.1^{\circ} \mathrm{E}, 213 \mathrm{~m}$ & $\mathrm{AOD}, M_{B}$ & $\begin{array}{l}\text { Microtops, } \\
\text { Aethalometer }\end{array}$ \\
\hline Dehra Dun & $30.34^{\circ} \mathrm{N}, 78.04^{\circ} \mathrm{E}, 690 \mathrm{~m}$ & AOD & MWR \\
\hline Patiala & $30.33^{\circ} \mathrm{N}, 76.46^{\circ} \mathrm{E}, 251 \mathrm{~m}$ & AOD & MWR \\
\hline Kullu & $31.9^{\circ} \mathrm{N}, 77.1^{\circ} \mathrm{E}, 1155 \mathrm{~m}$ & $\mathrm{AOD}$ & MWR \\
\hline Nainital & $29.2^{\circ} \mathrm{N}, 79.3^{\circ} \mathrm{E}, 1950 \mathrm{~m}$ & $\mathrm{AOD}, \mathrm{NSD}, M_{T}, M_{B}$ & $\begin{array}{l}\text { MWR, OPC, HVS, } \\
\text { Aethalometer }\end{array}$ \\
\hline Kanpur & $26.4^{\circ} \mathrm{N}, 80.3^{\circ} \mathrm{E}, 142 \mathrm{~m}$ & $\mathrm{AOD}, M_{B}$ & CIMEL, Aethalometer \\
\hline Kharagpur & $22.3^{\circ} \mathrm{N}, 87.3^{\circ} \mathrm{E}, 40 \mathrm{~m}$ & $M_{B}$ & Aethalometer \\
\hline Dibrugarh & $27.3^{\circ} \mathrm{N}, 94.6^{\circ} \mathrm{E}, 104 \mathrm{~m}$ & AOD & MWR \\
\hline
\end{tabular}

Abbreviations: AOD: Aerosol Optical Depth, $M_{B}$ : Mass concentration of BC, $M_{T}$ : Mass concentration of total aerosols and NSD: Number size distribution.

MWR: Multi-Wavelength Radiometer; MTPS: Microtops instrument; OPC: Optical particle counter; HVS:

High volume sampler; CIMEL: Cimel radiometer, QCM: Quartz crystal microbalance impactor, ELPI:

Electrostatic Low Pressure Impactor.

Table 2. Details of the cruise of ORV Sagar Kanya during ICARB.

\begin{tabular}{lllr}
\hline Cruise leg & \multicolumn{1}{c}{ Period } & \multicolumn{1}{c}{ Regions covered } & $\begin{array}{r}\text { Days } \\
\text { sailed }\end{array}$ \\
\hline Dry run & $\begin{array}{l}\text { March 09 to } \\
\text { March 13,2006 }\end{array}$ & $\begin{array}{l}\text { Goa to Chennai, along the coastal Arabian } \\
\text { Sea, around Sri Lanka and coastal Bay of } \\
\text { Bengal }\end{array}$ & 5 \\
SK223 A & $\begin{array}{l}\text { March 18 to } \\
\text { April 13, 2006 }\end{array}$ & $\begin{array}{l}\text { Chennai to Kochi, surveying the entire } \\
\text { BoB and northern IO and south coastal } \\
\text { Arabian Sea }\end{array}$ & 28 \\
SK223 B & April 18 to May & $\begin{array}{l}\text { Kochi to Goa surveying the entire Arabian } \\
\text { Sea }\end{array}$ & 24 \\
\hline
\end{tabular}

sampling instruments were installed at the fore of the B deck (figure 2, bottom) so that they also sample the same ambient air as that by the indoor analysers. These inlets drew air from the port side of the ship, about 1 meter off the ship's hull and $\sim 10 \mathrm{~m}$ above the water level. The inlets were so configured that the air came on to them as the ship moved so that the sampling was into the wind, devoid of any contamination from the ship.
Besides, the ship was continuously in motion (for $>22 \mathrm{~h}$ a day), except for short stoppages for the launching of balloons. Even during this period, the ship was positioned such that the winds arrive from the port side, while the balloons are launched from the starboard side to ensure that the data were always uncontaminated. During the port calls, all the instruments were switched off once the ship entered the berth. A list of major instruments 
(a)

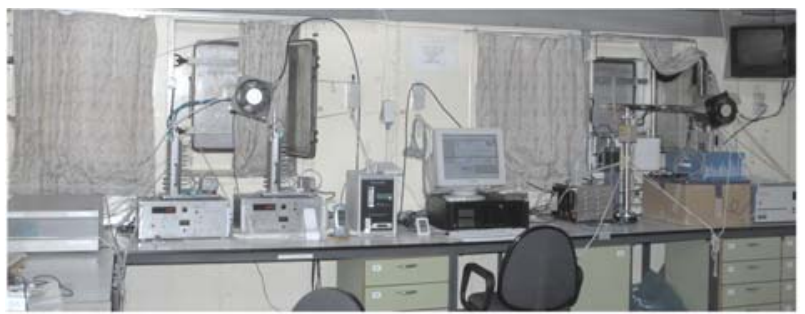

(b)

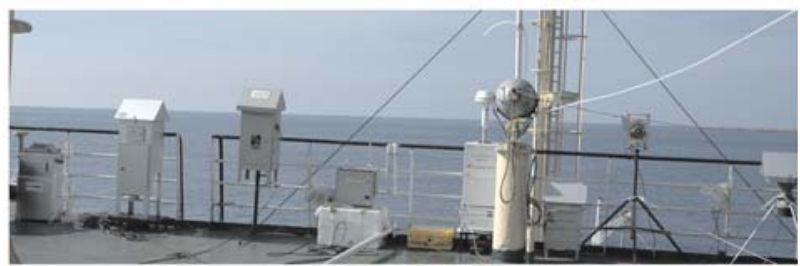

Figure 2. (a) Photograph of the aerosol and gas laboratory on the B deck of the ORV showing the different instruments connected to the community air inlets. (b) An array of outdoor aerosol instruments on the B deck sampling into the incoming air.

operated onboard the ORV during ICARB is given in table 3 , along with references to the instrumentation and data deduction.

Daily balloon ascents were made from the ship for measuring the altitude profiles of meteorological parameters, using GPS based Vaisala sondes. Ozonesonde ascents were made on alternate days. These provided high-resolution altitude profiles up to the mid-stratosphere (25 to $35 \mathrm{~km})$. Other onboard measurements included sun photometer measurements of spectral AOD (aerosol optical depth), column ozone, column water vapour (using sun photometer and GPS), and radiative fluxes in the UV, visible and total short wave. The ORV also carried onboard two automatic weather stations and a Doppler sodar for boundary layer measurements.

\subsection{The air segment}

The air segment of ICARB was executed using the aircraft of the National Remote Sensing Agency (NRSA), which dedicated one of its propeller aircraft (Beechcraft 200, used mainly for aerial survey). The sorties were carried out from five bases, two each on the east and west coasts of India and one from the interior continent. The sorties from each base were carried out in close coordination with the network and cruise operation, so that complementary, near simultaneous surface measurements are ensured around the period and location of the airborne measurements. The sorties were planned to be as close to the ORV tracks in the adjoining oceanic region as was possible. The sorties were carried out during the daytime and night-time. While the night-time sortie was dedicated for vertical profiling of aerosol extinction using a micro-pulse lidar mounted (in down-looking mode) over the optical flat window of the aircraft, the daytime sorties made in situ measurements of a number of parameters of aerosols and gases in the lower atmospheric region up to $\sim 3 \mathrm{~km}$ from the ground, the ceiling height of the aircraft permissible in unpressurised condition. In all, 26 sorties were made from five bases, as outlined in figure 3(a). Each station had a suit of sorties consisting of the following:

- One high-resolution profiling of the aerosol parameters during the forenoon period, after the ABL has evolved. This was aimed at understanding structures if any in the profile and the role of the atmospheric dynamics on them. During this, the aircraft climbed the altitudes in a stepand-staircase mode from ground to $3000 \mathrm{~m}$ in 8 levels (at 500, 800, 1100, 1400, 1700, 2000, 2500 and $3000 \mathrm{~m}$ ); but of short horizontal extents. This profile was made over the oceanic region, adjacent to the base, about $50 \mathrm{~km}$ offshore and thus represented the scenario over coastal ocean.

- A longitudinal profile, where the measurements were made across the longitudes, from the base into the oceanic atmosphere over a longitudinal span of $\sim 4^{\circ}$, to look for gradients over the ocean. Measurements were made only at two altitudes, $500 \mathrm{~m}$ (well within the ABL) and $1500 \mathrm{~m}$ (above the ABL, but below the trade wind inversion level), so that appreciably long latitudinal/longitudinal coverage is ensured within the available flight window.

- A latitudinal profile, along the coastline as far as possible, following the same criteria discussed for the sortie no 2 above. Two sorties were made in this category to get a wide coverage.

- One night-time sortie, exclusively for the micropulse lidar observation, during which the aircraft was pressurized and taken to an altitude of $8 \mathrm{~km}$ from where the lidar was operated in a downlooking mode, flying from the land towards the ocean and back.

The list of instruments operated in the air segment and the parameters measured are given in table 4 . The ambient air was aspirated into the aircraft using stainless steel inlet pipe, fitted under the nose of the aircraft, such that the inlet opens into the incoming air as the aircraft flies. The operating conditions and flow rate of the instruments were set to ensure sampling of as large a volume as possible within the shortest time permitted, still all conditions were within the permitted limits of each instrument. Wherever needed, the data were corrected for the change in the pumping speed with decrease in the ambient pressure as the aircraft climbed to higher levels (Moorthy et al 2004). 


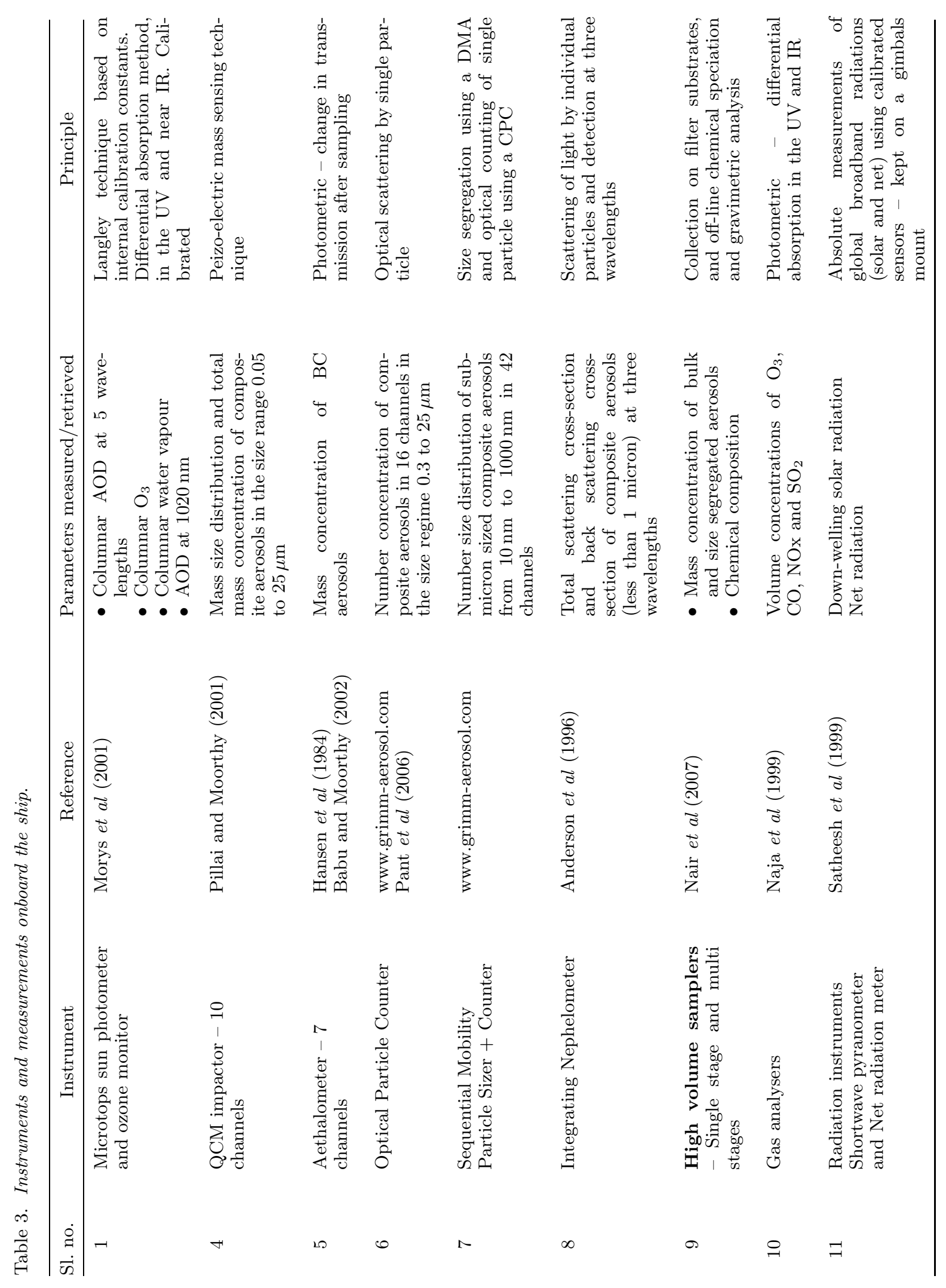




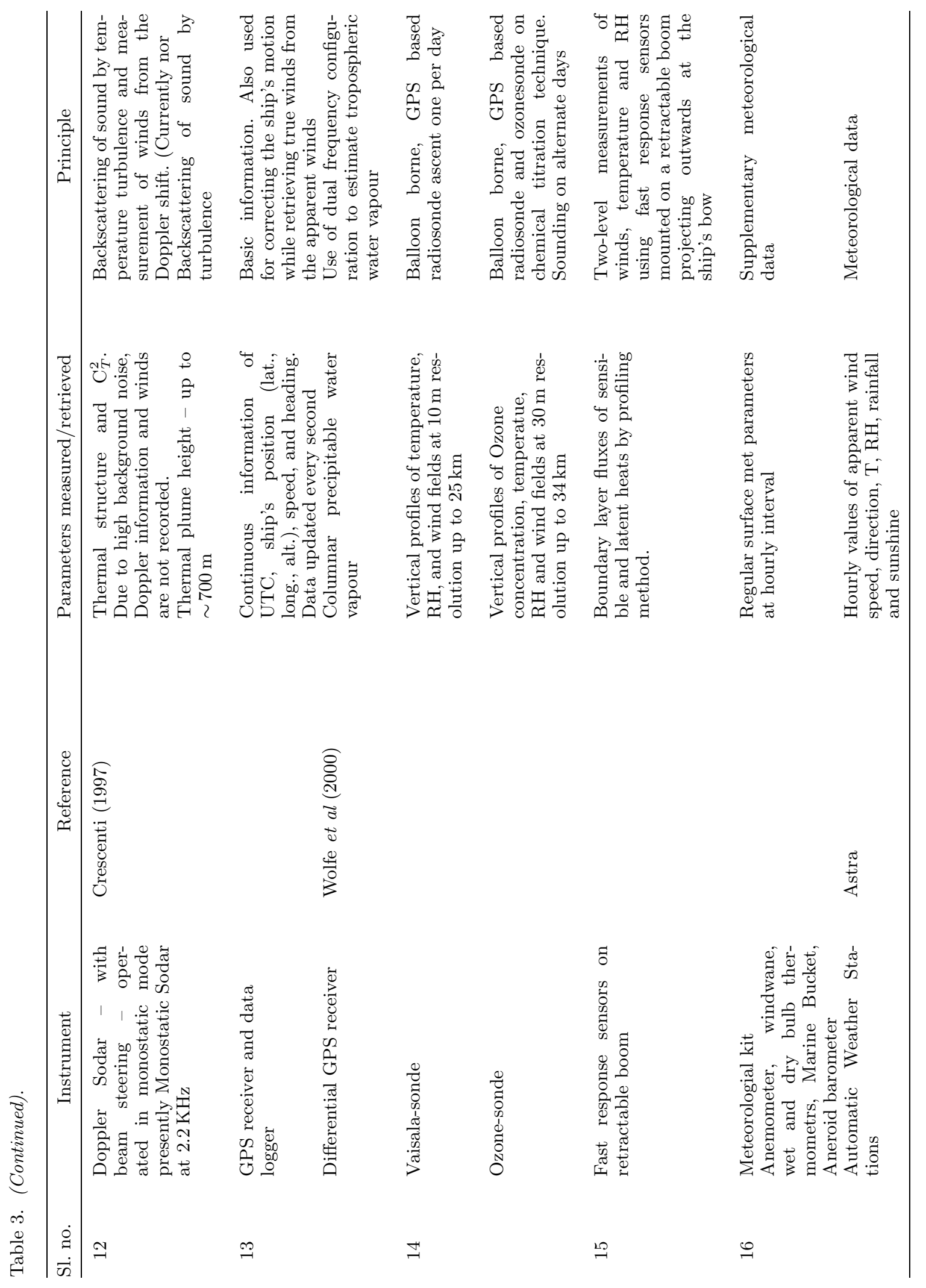




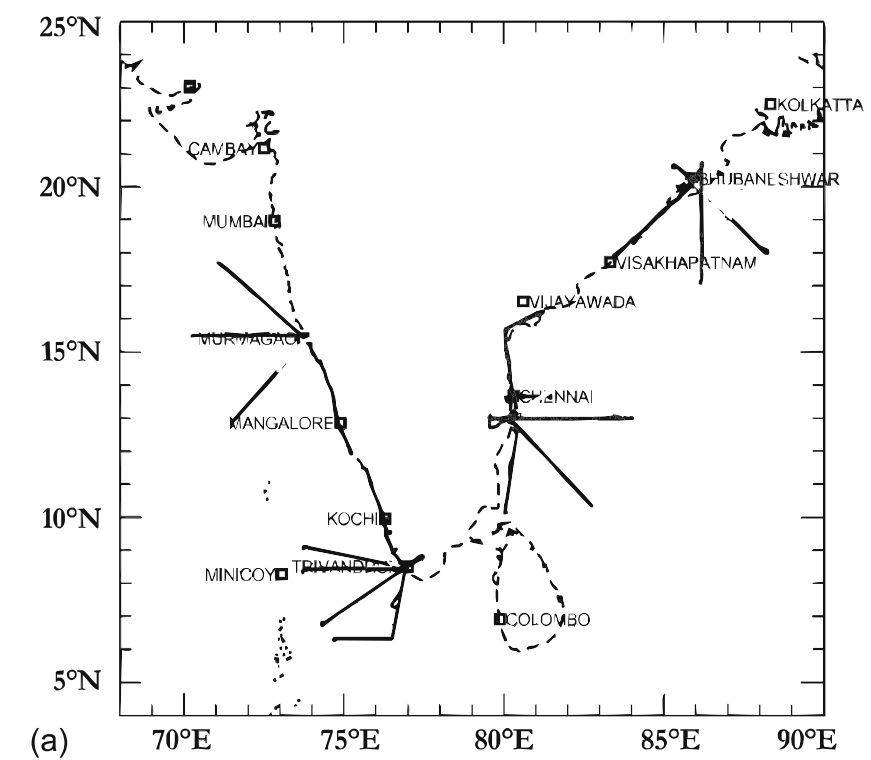

(a)

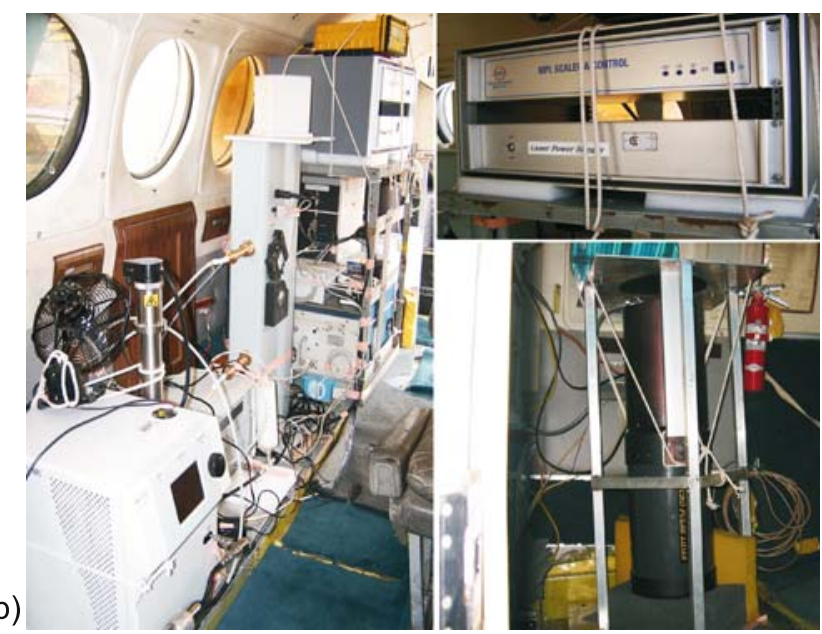

Figure 3. (a) Details of the aircraft sorties during ICARB. The lines from each base show the different sorties carried out from that base. (b) The instrumental setup in the aircraft.

The Micro Pulse Lidar (MPL) required no aspiration of ambient air and was to be operated from a high altitude of $\sim 8 \mathrm{~km}$ and as such, the aircraft was pressurized during this sortie. To avoid the large background and strong ground reflections, the MPL flight was restricted to early night-time. The MPL (model MPL1000 of Science and Engineering Services Inc., USA) was fitted upside down in the aircraft. The MPL uses an AlGaAs diode pumped Nd-YLF laser, converting the primary radiation at $1047 \mathrm{~nm}$ to its second harmonic at $523.5 \mathrm{~nm}$, at a pulse energy of $10 \mu \mathrm{J}$ and a pulse repetition frequency (PRF) of $2.5 \mathrm{kHz}$. The collected data were analysed following the particulatefree zone approach and described in Satheesh et al (2006). The optical flat window of the aircraft meant for its survey operations provided the ideal window for lidar operations. The configuration of the instruments within the aircraft is shown in figure 3(b).

\subsection{Satellite component}

For such a large field experiment covering vast areas of the land and ocean, it is imperative to have adequate complementary satellite data and derived products. For ICARB, the cloud pictures from METEOSAT and KALPANA satellites, and AODs derived from MODIS and NOAA-18 AVHRR were extensively used. Besides, extensive use of the NCEP/NCAR reanalysis data as well as the NOAA HYSPLIT air trajectory models were extensively used, both during the campaign for fine-tuning the cruise tracks and experimental schedules, as well as during the post-cruise data analysis.

\section{Results}

In the following, we present a few preliminary results of ICARB and evaluate them for the spatiotemporal heterogeneities and against the backdrop of earlier investigations in this region. More detailed results are provided in several companion papers in this issue, by the respective investigating teams.

\subsection{Spatial distribution of aerosol optical depth over the Arabian Sea and BoB}

The spectral AOD measurements, made onboard the ORV during its Arabian Sea leg (SK223B), are combined to examine the average spatial distribution in figure 4. In doing so it is implicitly assumed that the spatial pattern remained statistically stationary during the rather short span of $\sim 24$ days of the cruise. This is also justified by the earlier measurements over different parts of Arabian Sea during this season (e.g., Moorthy and Satheesh 2000; Moorthy et al 2005a). It is quite interesting to note from the figure that:

- Except at two pockets of moderate to high AODs, over most of the Arabian Sea the AODs are quite low, varying between 0.06 and 0.30 at $500 \mathrm{~nm}$. In several parts of the central Arabian Sea, the values were between 0.06 and 0.12 .

- There is one region, off the coast of Mangalore, where the AODs are very high, reaching as high as 0.85 . This region of high AOD and high aerosol concentration appears to be a consistent feature, and was reported during several earlier cruises (Moorthy and Saha 2000; Parameswaran et al 1999; Ramachandran 2004). During a road campaign of 2004 winter, Moorthy et al (2005b) have reported high particulate mass 
Table 4. Instruments operated onboard the aircraft.

\begin{tabular}{ll}
\hline \multicolumn{1}{c}{ Instruments } & \multicolumn{1}{c}{ Parameters measured } \\
\hline Aethalometer & Black carbon mass concentration $\left(M_{B}\right)$ \\
Nephelometer & Aerosol scattering coefficient at 450,550 and $700 \mathrm{~nm}$ \\
Scanning mobility particle sizer & Aerosol number size distribution \\
Optical particle counter & Aerosol mass size distribution \\
Micro Pulse Lidar & Aerosol backscatter and extinction \\
Ozone analyzer & Ozone concentration \\
GPS receiver & Instantaneous position of the aircraft \\
\hline
\end{tabular}

loading along the coast around Mangalore. During the ICARB, this high is quite pronounced and strong.

- Another region, of smaller spatial extent, of moderately high AOD (0.3 to 0.4 at $500 \mathrm{~nm}$ ) is seen centered at $18^{\circ} \mathrm{N} ; 68^{\circ} \mathrm{E}$. It might be recalled that based on the INDOEX data of March 1998 and 1999, Moorthy and Saha (2000) have reported the occurrence of a region of high AOD around the same location, which they called the West Asian High, mainly because of its proximity to the west Asian region. In the same region, based on conductivity measurements, Kamra et al (2001) have reported a region of enhanced aerosol concentration. The high, observed in the present study, is in-line with the earlier findings, notwithstanding that it is much weaker than what was seen during the INDOEX. Besides this, there exists a very small region of moderate AOD off Mumbai.

- Over the rest of the Arabian Sea, the AOD is extremely low. It is also interesting to note that over the wide region bound between $56^{\circ} \mathrm{E}$ and $68^{\circ} \mathrm{E} ; 9^{\circ} \mathrm{N}$ and $15^{\circ} \mathrm{N}$, the AODs are low $(\sim 0.15$ at $500 \mathrm{~nm})$. In this same region, independent measurements of surface mass concentrations (using a QCM impactor onboard the same cruise) also revealed extremely low mass concentrations $\left(<15 \mu \mathrm{g} \mathrm{m}^{-3}\right)$ as reported by Nair et al (this issue).

At this juncture it would be interesting to examine the spatial distribution of AOD over the BoB. The spatial composite of AOD at $500 \mathrm{~nm}$ wavelength, is shown in figure 5(a) using the measurements from the first leg of the ocean segment of the ICARB onboard cruise SK223A, even though these data were obtained during March-April 2006, about one month prior to the AS measurements. In general, higher AODs prevailed over the BoB, compared to AS. In contrast to the AS pattern, there is a sharp latitudinal gradient in the $\mathrm{BoB}$, with the AODs increasing northward. Moderate-to-high AODs occur over the entire Head BoB, north of $15^{\circ} \mathrm{N}$ and as far as $92^{\circ} \mathrm{E}$ from the eastern coast of

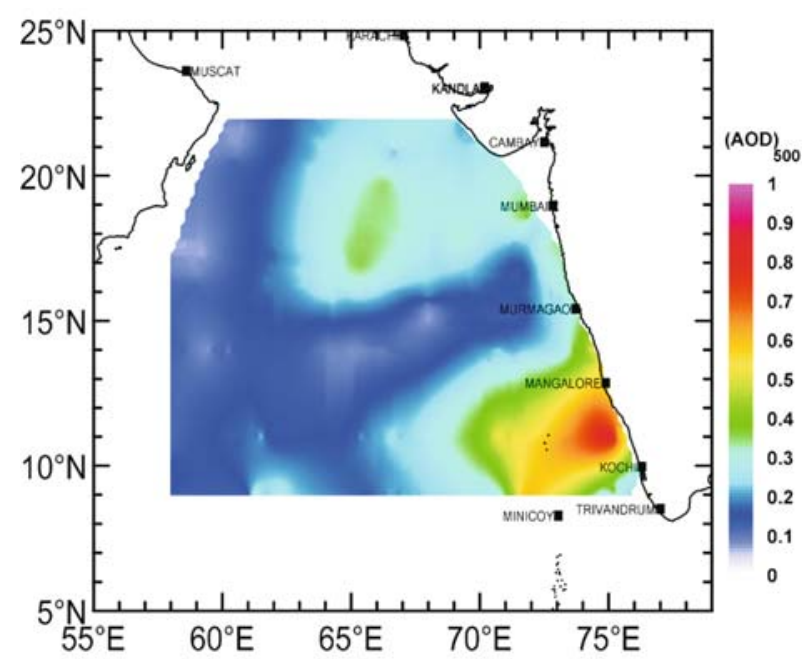

Figure 4. Spatial distribution of AOD at $500 \mathrm{~nm}$ over the Arabian Sea during ICARB.

Indian mainland. In this region, AOD at $500 \mathrm{~nm}$ is in the range 0.5 to 1 . Interestingly there occurs rather large region of approximately $3^{\circ} \times 3^{\circ}$ in size and centered about $17.4^{\circ} \mathrm{N}, 87.1^{\circ} \mathrm{E}$, where the AOD is extremely large, exceeding 0.8 and going as high as 1.1. We designate this as a 'detached high' due to its isolated nature, with no connection to the mainland. An examination of the prevailing winds (at 850 and $700 \mathrm{hPa}$ levels from the NCEP reanalysis data) revealed that this region was under the influence of a low-level anticyclonic circulation, which spatially confines the aerosols. The back-trajectory analysis revealed strong advection pathways from the northwest (west Asia and across the Indo Gangetic Plains). The spatial variation of AOD over the central Indian region during this period revealed strong impact of western advection (Beegum et al, this issue). Aircraft profiles (analysis yet to be completed) offBhubaneswar also showed the presence of regions of high aerosol concentration above $1.2 \mathrm{~km}$ altitude (probably associated with advection). Using collocated measurements of AOD and altitude profiles of aerosol extinction using a micro pulse lidar 

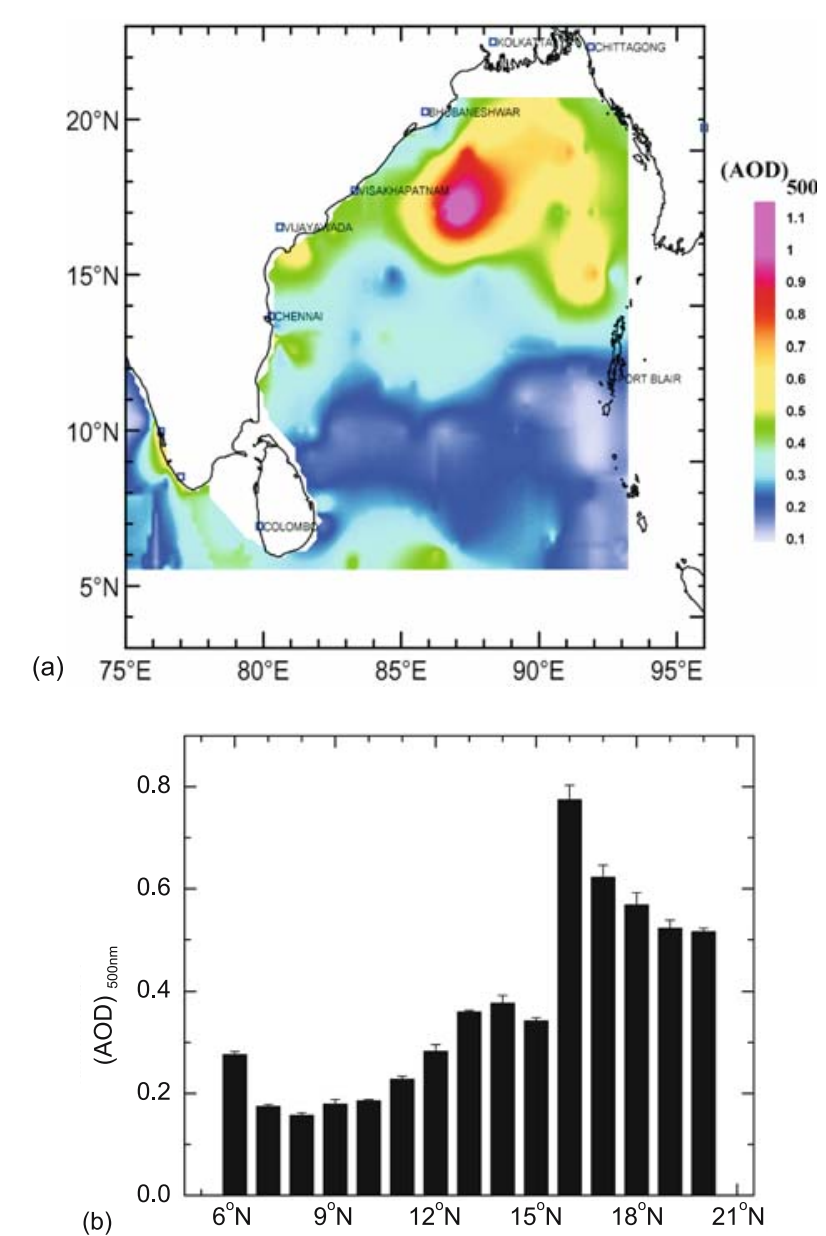

Figure 5. (a) Spatial variation of AOD at $500 \mathrm{~nm}$ over the Bay of Bengal. (b) Latitudinal variation of AOD over BoB. The error bars represent standard errors.

from Visakhapatnam, located on the east coast (figure 1), Niranjan et al (2007) have reported (episodic) occurrence of high-altitude aerosol layers during the months of March/April 2005, 2006, in the lidar-derived profiles, which produced an increase in the AOD by 0.05 to 0.25 . With the aid of HYSPLIT back-trajectory analysis they showed that the possible origin of these lavers could be advection of mineral dust from Arabia in $60 \%$ of the cases, while it could be of the IGP origin during the rest of the events. Thus it appears that the combined effects of this advection and the low-level anticyclonic circulation over the $\mathrm{BoB}$ resulting in a spatial confinement of aerosols might have led to the formation of the detached high over the ocean.

In figure 5(b) we show the latitudinal variation of AOD at $500 \mathrm{~nm}$, averaged over the longitudes $83^{\circ} \mathrm{E}$ to $92^{\circ} \mathrm{E}$ (so as to eliminate the values that are too close to the coast). It shows a gradual buildup from the lowest value $(\sim 0.17)$ at $8^{\circ} \mathrm{N}$ to reach the peak at $17^{\circ} \mathrm{N}$ and then a weak decrease. Below $5^{\circ} \mathrm{N}$, a very weak increase is depicted, the reason for this is not clear except that there exists a narrow

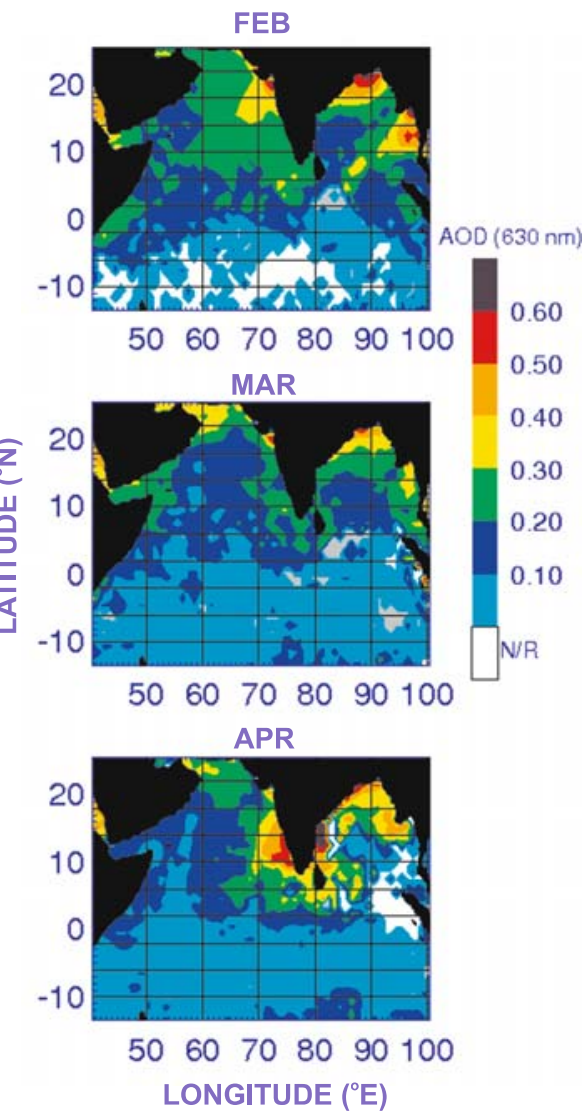

Figure 6. Monthly mean regional distribution of AOD derived from NOAA-18-AVHRR data during February, March, and April 2006. The white shade shows regions where AOD could not be retrieved due to clouds (courtesy K Rajeev et al, SPL).

shipping channel between 5 and $6^{\circ} \mathrm{N}$, which handles nearly $25 \%$ of the international ship traffic.

\subsection{Regional distribution of $A O D$ during February-April 2006 from satellite data}

In view of the above observations, which revealed significant differences from the earlier reports, the monthly mean spatial distribution of AODs (at the wavelength $630 \pm 50 \mathrm{~nm}$ ) over the AS, $\mathrm{BoB}$, and equatorial Indian Ocean (EIO) were examined. These AODs were retrieved from the Advanced Very High Resolution Radiometer (AVHRR) onboard NOAA-18 satellite (Level-1b Global Area Coverage data of the afternoon passes) using the operational satellite sensor calibration coefficients following the details outlined in Rajeev et al (2000). The results for three months, February, March, and April 2006, are shown in figure 6. The significant observation from figure 5 is the general conformity to the cruise observations during the month of April, where the high AODs (>0.5 at $630 \mathrm{~nm})$ off Mangalore coast and the low values (0.1 to 0.2) in the central Arabian 
Sea (bound between $55^{\circ} \mathrm{E}$ to $65^{\circ} \mathrm{E}$; and equator to $15^{\circ} \mathrm{N}$ ) are clearly seen in the bottom panel. Looking back to the temporal evolution of AOD, the upper panels of the same figure show that:

- In February, two distinct regions of high AOD values are observed over $\mathrm{BoB}$, one in the north and the other in the east off the Myanmar coast. Over most parts of the Arabian Sea, AOD is between 0.2 and 0.3 with relatively smaller spatial variation.

- The AODs significantly decrease from February to March, over the entire Arabian Sea and BoB. Over the Arabian Sea, except very near the continent, AOD is generally less than 0.2 in March and very low values are encountered particularly over the central and eastern parts.

Comparing these observations with the mean regional distribution of AOD obtained from 7 years' data over this region (Nair et al 2005), the major difference is that while the AOD distribution shows an increase over the eastern Arabian Sea from February to March in the mean pattern, it shows a decrease in the year 2006 .

\subsection{Spatial variation of Angström parameters over the Arabian Sea during ICARB}

By performing a regression analysis of the spectral AODs with the Angström relation (Ångström 1964) $\tau_{p \lambda}=\beta \lambda^{-\alpha}$ (where $\tau_{p \lambda}$ is the AOD at wavelength $\lambda$ expressed in micrometer) the wavelength exponent $\alpha$ and turbidity coefficient $\beta$ are evaluated. While the wavelength exponent is a measure of the ratio of accumulation mode to coarse mode concentrations of the columnar aerosols (and hence an indicator of the aerosol columnar size distribution), the coefficient $\beta$ is a measure of the column abundance of particles. In figure 7(a) we show the spatial variation of $\alpha$ over the Arabian Sea while that of $\beta$ is examined in figure $7(b)$. The most striking features are:

- The southern Arabian Sea (south of $15^{\circ} \mathrm{N}$ ) is characterized by high values of $\alpha$ (and hence steep AOD spectra) with values in the range 0.85 to 1.1, indicating high relative abundance of accumulation mode aerosols. Compared to this, the northern Arabian Sea is dominated by coarser mode aerosols and $\alpha$ goes well below 0.6 . These coarse mode aerosols could be associated with either sea spray aerosols or transported mineral dust or both.

- Over most of the Arabian Sea $\beta$ remains very low (below 0.15), showing low columnar aerosol loading except for the two pockets, where high AODs were seen in figure 4. However, off Mangalore coast, we note a pocket of enhanced
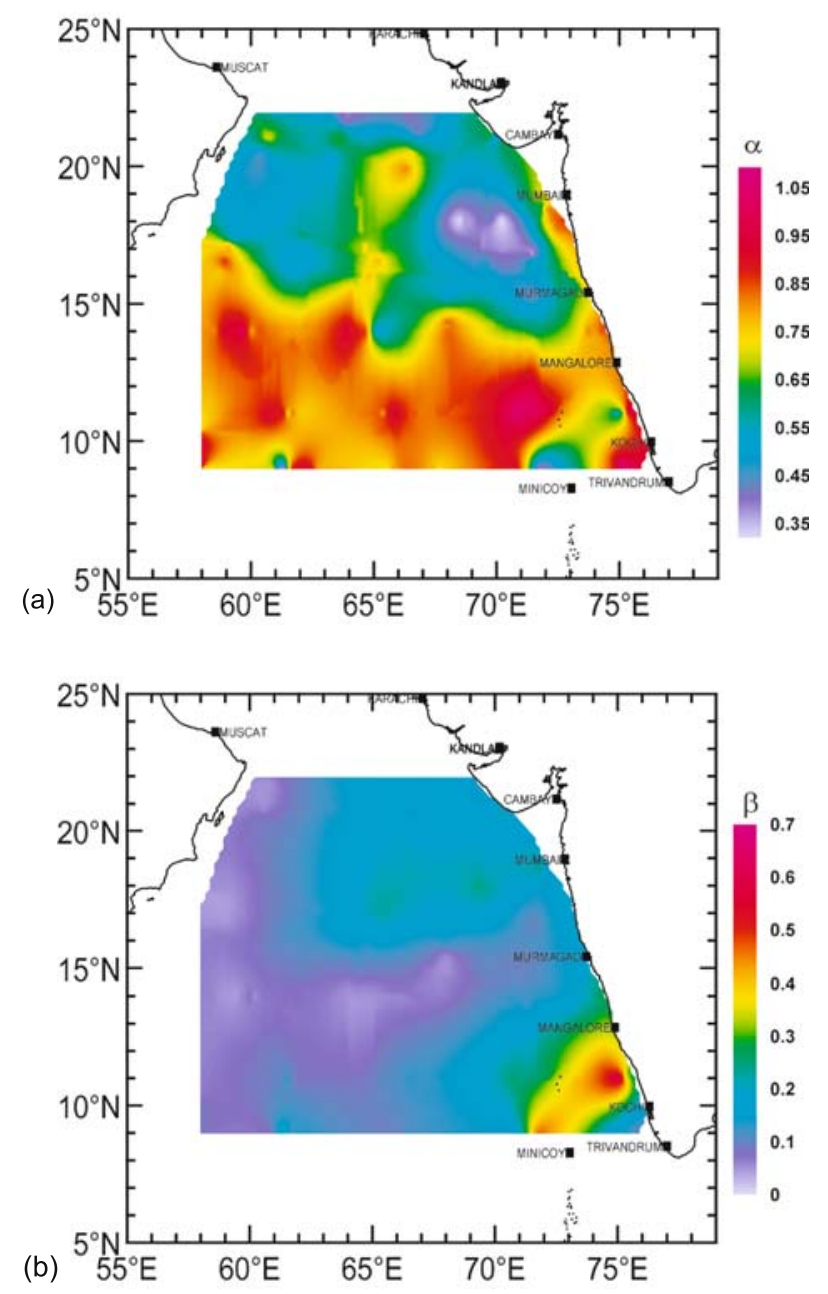

Figure 7. (a) Spatial distribution of the Ångström exponent over the Arabian Sea during ICARB. (b) Spatial distribution of the turbidity coefficient over Arabian Sea.

abundance of accumulation mode particles (high $\mathrm{AOD}$, high $\alpha$, and high $\beta$ ). On the other hand at the second pocket in the central AS where AOD was moderate, even though $\beta$ also was moderate, $\alpha$ was low implying that the concentration of accumulation mode aerosols was low. It is also important to note that these findings are consistent with the mass concentration measurements of aerosols near the surface with the QCM (Nair et al, this issue), which showed higher accumulation fraction near the coast and in the southern Arabian Sea, while in the northern AS the coarse mode fraction was higher.

\section{$5.4 A O D$ distribution over mainland and islands}

Spectral AODs, obtained regularly during the ICARB period from the network observatories spread over the Indian mainland and adjoining islands (figure 1), are averaged over the months and the spatial composites are shown in 


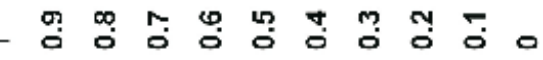

(AOD)

500

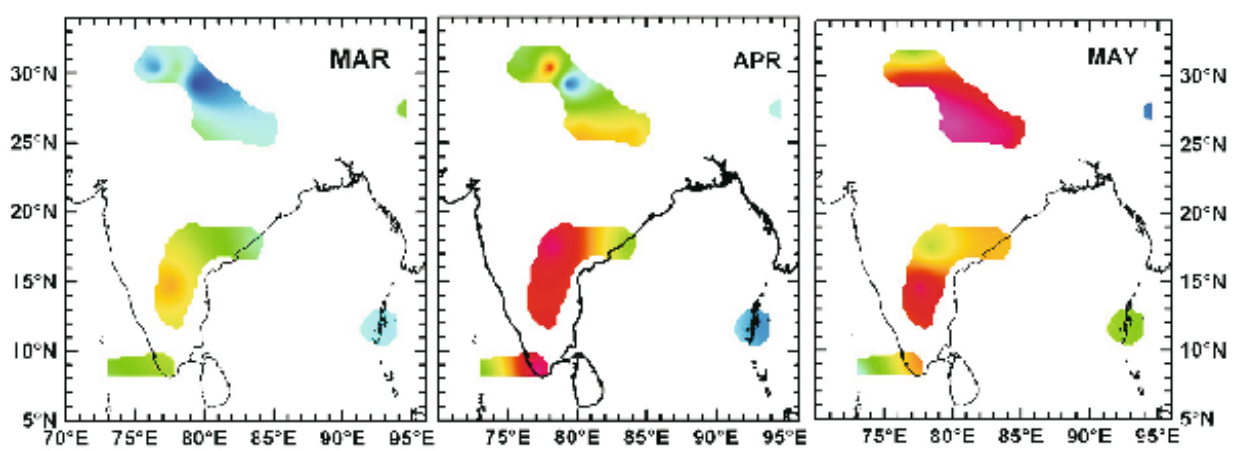

Figure 8. Spatial variation of AOD at $500 \mathrm{~nm}$ derived from the network stations over the mainland and islands: Panels from left to right represent respectively the monthly mean variations for March, April, and May 2006.

figure 8(a-c, respectively for the months of March, April and May, 2006). In making this plot, the AODs estimated for each station was assumed to be spatially homogeneous over a spatial grid of $1^{\circ}$ about the measurement station. Unlike over the oceans, spectral AODs over the land showed considerable variations spatially and temporally. While at the southern peninsular stations the AODs decreased towards May after a sharp peak in April, in the north-Indian regions the AODs increased continuously from moderate values in March to very high values in May. This is in general conformity to the climatological pattern reported for this region (Moorthy et al 1999, 2007). These are mainly attributed to the combined effects of (i) the prevailing weak, and anticyclonic, low-level winds, which confine the aerosols spatially over the peninsula, (ii) lifting of mineral dust from the arid and semi-arid regions of the central and western India by the strong convective motions during premonsoon and summer months and (iii) the longrange transport of dust from the arid region of west Asia and western India across the Indo Gangetic Plain (IGP), including the Himalayan stations. Compared to these features over the mainland, island stations as well as the northeastern station DBR on the mainland showed considerably low AODs indicating prevalence of cleaner environment. This is mainly due to (a) the isolated nature of the islands and the low level of anthropogenic activities in them, and (b) the tall Himalayan ranges surrounding DBR, which restrict transport of pollutants from other regions.

The Ångström exponents, derived from the AOD spectra, indicated enhanced coarse mode loading in the north Indian regions, compared to southern India. Moreover, as the months progressed from March to May, the dominance of coarse mode aerosols increased in the size spectrum over the entire Indian mainland, still maintaining the above regional distinctiveness. Enhanced longrange transport of aerosols (mainly dust), from the west Asia and north west India, contributed significantly to the enhancement of AODs and in the lowering of the Angström exponent over the mainland; if it is the peninsular regions that are more impacted in April, the north Indian region including the IGP get affected the most during May. More details on these are given in a separate study (Beegum et al, this issue).

\subsection{Offshore extent of urban impact and role of long-range transport}

During SK223A, the ship called twice at the port of Chennai within a period of 18 days and the data collected while the ship was sailing into and out of the port and sailed in its proximity were used to estimate the extent of significant spatial intrusion of the urban aerosols over to the ocean. For this, the continuous measurements of AOD, and mass concentrations $\left(M_{B}\right)$ of aerosol black carbon near the surface (made using the aethalometer) and the number concentration $\left(N_{T}\right)$ of the composite aerosols (made using the optical particle counter) were examined. The panels, respectively from the top to bottom in figure 9 show the spatial variation of the above parameters. The most important findings are:

- Near the surface, there is a large concentration of aerosols close to the port and it decreases as we move away. This is true for both $\mathrm{BC}$ and composite aerosols (as seen from the middle and bottom panels in the figure). This is attributed mostly to the anthropogenic sources in the urban area and at the port. In both these cases impact becomes insignificant and indistinguishable from 

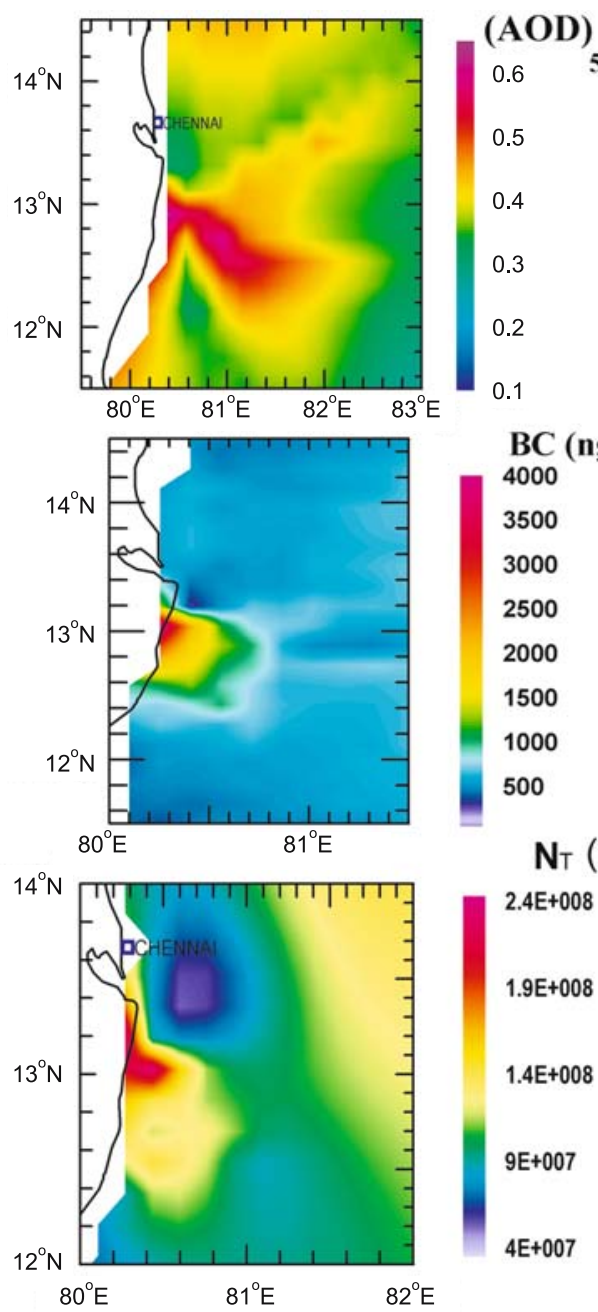

Figure 9. Spatial variation of various aerosol parameters over Bay of Bengal, adjacent to the Chennai Port. Panels from the top show respectively the spatial variations of columnar AOD at $500 \mathrm{~nm}$, the mass concentrations of $\mathrm{BC}$, and the number concentration of composite aerosols (both near the surface). Note that while the impact is only over a very short spatial extent at near surface (top and middle panels), on AOD it is seen extending to $>250 \mathrm{~km}$.

the background beyond $80.8^{\circ} \mathrm{E}$ (i.e., within a distance of $70 \mathrm{~km}$ offshore).

- The AOD (top panel in figure 9), however, shows that the high region extends as much as up to $82.4^{\circ} \mathrm{E}$ (i.e., an offshore extent of $>250 \mathrm{~km}$ ).

These observations are important as they reveal the difference in 'far-field effect' as seen at the surface and seen through the vertical column. The possible causes for this effect are the presence of elevated layers of high aerosol concentration or long-range transport of aerosols at higher levels through airmass trajectories. While the local ABL would contribute more to the formation of the elevated layers through its dynamics, longrange transport is more synoptic in nature. The large convective heating in and around the urban

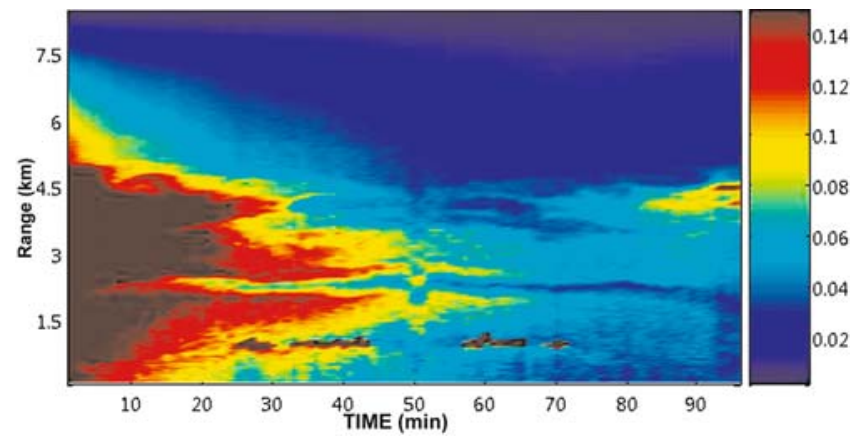

Figure 10. Micro Pulse Lidar profiles during early nighttime on 03 April 2006 of the altitude profile of aerosol extinction coefficient $\left(\mathrm{km}^{-1}\right)$ over the Bay Bengal off Chennai coast showing the presence of elevated layers going as deep as $400 \mathrm{~km}$ offshore.

landmass (during the campaign period the air temperature at Chennai was in the range 36 to $38^{\circ} \mathrm{C}$ ) would lead to a deeper convective boundary layer, which would transport the pollutants at the surface to higher levels of the atmosphere. These then merge with the prevailing winds, when the ABL collapses in the evening and remains as elevated layers of enhanced concentration in the residual layer. To examine this, the aerosol extinction profile obtained using the micro pulse lidar onboard the aircraft sortie from Chennai during the early night hours of April 3 were examined in figure 10 . The colour scale on the right shows the extinction coefficient variation in $\mathrm{km}^{-1}$. The $\mathrm{X}$ axis shows time elapsed in minutes after the aircraft has stabilized at the $8 \mathrm{~km}$ level over Chennai, with the origin corresponding to its position at several $\mathrm{km}$ inland of the Chennai coast. The y axis is the altitude from the ground level. The track was normal to the coast into the BoB. The aircraft flew for 56 min along this track before retracing the path. During the first $4 \mathrm{~min}$ of the onward leg, the aircraft was over the land and the MPL data during this period is discarded due to contamination from the high reflection from land surface. As such, in the figure the portion up to $51 \mathrm{~min}$ corresponds to the onward leg, and that after $52 \mathrm{~min}$ corresponds to the same region of the onward leg, but in the reverse order, as the aircraft retraced its path. The MPL was switched off about 5 min prior to the aircraft reaching the coast and thus the extinction values in figure 10 at $100 \mathrm{~min}$ are obtained while the aircraft was still well over BoB and would approximately correspond to the region identified by $5 \mathrm{~min}$ in the onward leg. The region where the aircraft turned back was $\sim 400 \mathrm{~km}$ offshore, over the BoB, is identified by a short discontinuity in figure 10 at $\sim 52 \mathrm{~min}$. The flight commenced around 18:50 local time (after sunset) and the measurements started at 19:12 and continued till 20:58. The figure shows several features: 


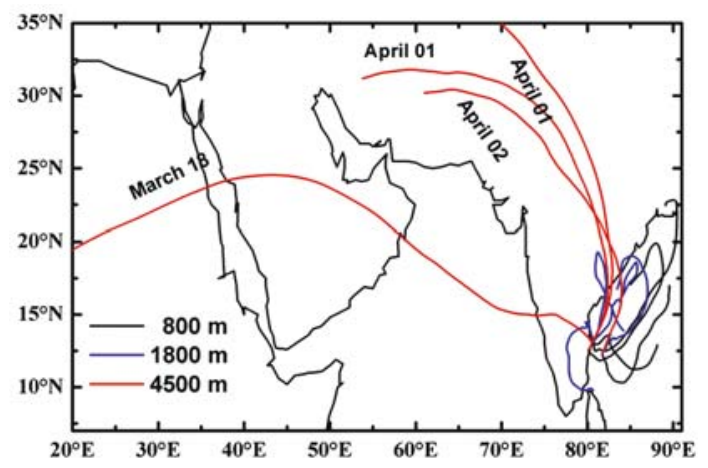

Figure 11. Five-day air back trajectories (NOAA HYSPLIT model), arriving at three levels off Chennai coast during the measurement days, showing the role of long-range transport.

- Very close to the surface, the extinction coefficient decreases rapidly as the aircraft moved away from the coast from its peak value of $\sim 0.15 \mathrm{~km}^{-1}$ over the coast to around half its value within a distance of $\sim 80 \mathrm{~km}$ offshore (after $16 \mathrm{~min}$ of the flight, which included a few min over the land also) almost in-line with the pattern seen in figure 9 for $\mathrm{M}_{B}$ and $N_{T}$.

- However, figure 10 also shows the occurrence of three strong, elevated layers; one at about $1.8 \mathrm{~km}$ altitude and extending as far as $\sim 300 \mathrm{~km}$ into the $\mathrm{BoB}$, with very high value $\left(\sim 0.13 \mathrm{~km}^{-1}\right)$ for the extinction coefficient and the other centered around $3.7 \mathrm{~km}$ and extending, again, as far as $\sim 300 \mathrm{~km}$ into the ocean. The third one, at around $4.2 \mathrm{~km}$, extended up to $\sim 250 \mathrm{~km}$. It is quite possible that these elevated layers of enhanced particle concentration would have contributed significantly to the offshore spread of the high AOD.

- During the return leg (20:08 to 20:58) the lower two layers weakened significantly, while top layer continued to be strong. This would mean that the top layer (at $4.2 \mathrm{~km}$ ) would be associated with the long-range transport while the bottom layers could be more associated with the ABL dynamics discussed earlier. After sunset, the convective cells weaken and the nocturnal layer forms, which inhibits thorough vertical mixing. This might be leading to the rapid decrease in the extinction coefficient in the return leg.

To examine the role of long-range transport at the higher level $(4500 \mathrm{~m})$ as seen in the lidar profile, we computed 5-day isentropic airmass back trajectories using the NOAA HYSPLIT model (http://www.arl.noaa.gov/ready/hysplit4.html).

The results are shown in figure 11 for March 18, April 01 and April 02, when the ship was close to Chennai. In each case we examined trajectories arriving at three levels, $800 \mathrm{~m}$ (within the

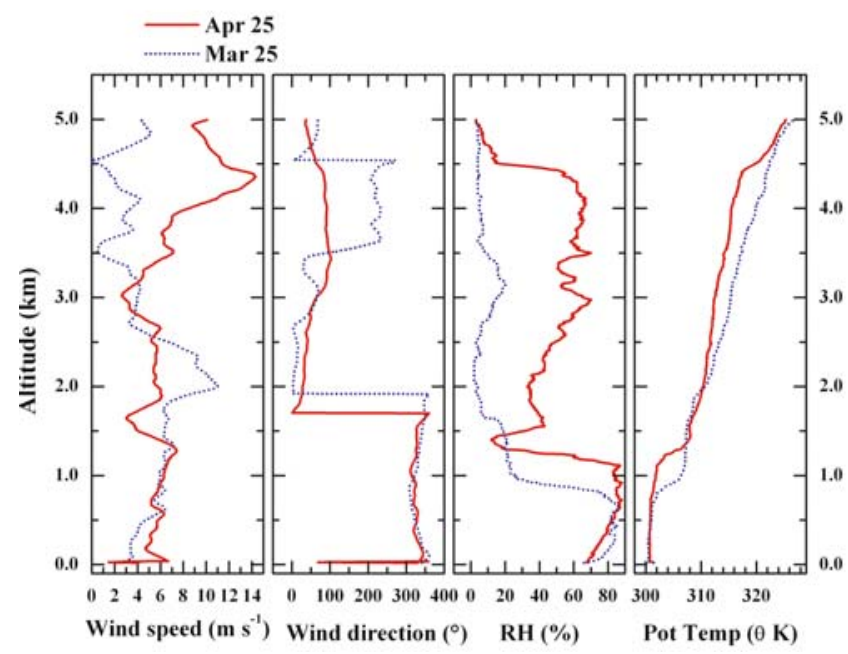

Figure 12. Two typical altitude profiles derived from the Vaisala ascents from the ship. The profile for March is over the northern $\mathrm{BoB}$ and that of April is over the central Arabian Sea (courtesy - PK Kunhikrishnan and D P Alappattu, SPL).

$\mathrm{ABL}$ ), $1800 \mathrm{~m}$ (just above the ABL, but in the entrainment zone) and at $4500 \mathrm{~m}$ (in the free troposphere) above the ground level. The two higher altitudes also coincided with the centre of the two elevated layers seen in figure 10. It is quite interesting to note that while at $800 \mathrm{~m}$ and $1800 \mathrm{~m}$ the trajectories are mostly confined over coastal $\mathrm{BoB}$, the trajectory at $4500 \mathrm{~m}$ shows very clearly the existence of pathways, which favour advection of aerosols from west Asia, along northwest and central continental India to the observing site. Thus long-range transport of aerosols at higher levels appears to be a strong candidate favouring the longer offshore spatial extent of aerosols seen in the AOD. The potential role of such advection was seen on the AODs over the mainland stations also during this period (Beegum et al, this issue), again stronger at higher altitudes. Because of their synoptic nature, the elevated layer contributed by this advection, persists even late into the night. In contrast, closer to the surface, and in the MABL, as the trajectories are basically oceanic in nature, the ABL dynamics would be controlling the formation and dissipation of the elevated aerosol layers. As such, they disappear shortly after sunset, because the convective boundary layer collapses and the nocturnal boundary layer (forming close to the surface) inhibits vertical mixing.

\subsection{Vertical structure of the lower atmosphere - a comparison between the two oceans}

The high-resolution balloon sounding using GPS sonde payloads using the Vaisala system was carried out daily from the ship. This provided highly useful information on the MABL characteristics. 


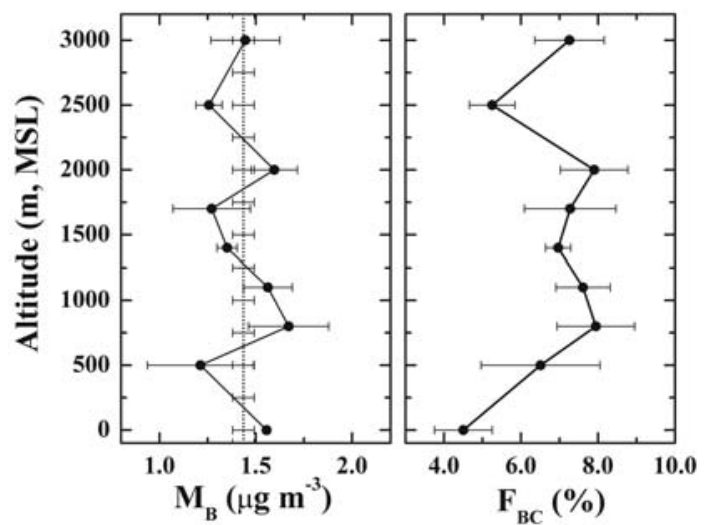

Figure 13. (Left panel) Altitude profile of the mass concentration of BC off Bhubaneswar obtained on 28 March 2006 showing structures associated with ABL dynamics; and (right panel) the altitude profile of BC mass fraction $\left(F_{B C}\right)$ at the same location showing an increase in the $F_{B C}$ at higher altitude.

Two typical profiles (from $0-5 \mathrm{~km}$ ) are shown in figure 12, where the continuous line in red shows the profile over central Arabian Sea obtained on April 25, while the dotted blue lines show the profiles for the BoB, obtained for March 25, 2006. The panels from left to right show respectively the profiles of wind speed, direction, relative humidity, and potential temperature. Over the BoB the well-mixed region extends vertically up to $\sim 900 \mathrm{~m}$ ( $\theta$ remaining steady in the extreme right panel). In this region the winds are weak northerlies and $\mathrm{RH}$ is quite high. In comparison, over central Arabian Sea, the well-mixed layer is deeper, extending to $\sim 1400 \mathrm{~m}$ and the winds are stronger, northerlies. The region of high $\mathrm{RH}$ also extends up to this height. Above the mixed layer, we can see the trade wind inversion layer at $\sim 2 \mathrm{~km}$ over the $\mathrm{BoB}$, where the wind speed goes as high as $11 \mathrm{~m} \mathrm{~s}^{-1}$ and then decreases towards higher heights. In the region 3.5 to $4.5 \mathrm{~km}$ the winds shift indicating westerly advection of extremely dry air $(\mathrm{RH}<30 \%)$. This might be associated with the long-range advection phenomenon seen in figure 11 . Such a phenomenon is not seen in the profile over the Arabian Sea.

\subsection{Altitude profile of $B C$ mass concentrations off east coast of India}

From the airborne measurements of the mass concentrations $\left(M_{B}\right)$ of $\mathrm{BC}$, the altitude profiles were examined. In the left panel of figure 13, a typical altitude profile, obtained off Bhubaneswar $\left(19.4^{\circ} \mathrm{N}\right.$; $86.7^{\circ} \mathrm{E}$ ) on 28 March 2006 is shown, where the points are the mean values and the bars through them are the standard deviations of the mean. The surface value is obtained from the shipboard measurements around the same region close to the aircraft measurements. The figure shows:

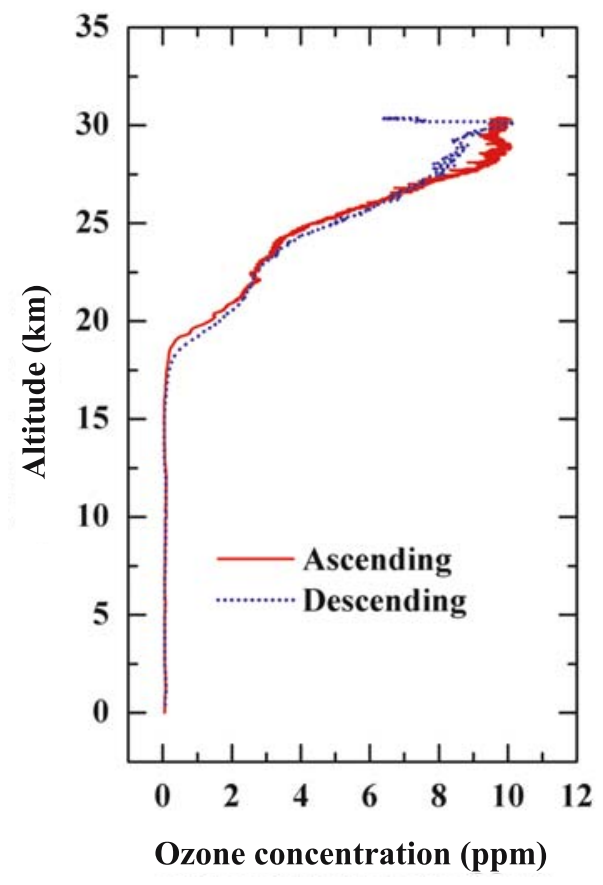

Figure 14. Vertical profile of ozone, obtained over north west coastal BoB off Bhubaneswar on 20 March 2006, from the shipboard ozonesonde ascent (courtesy - Shyam Lal and Venkataramani, PRL).

- A steady BC concentration of $1.4 \mu \mathrm{g} \mathrm{m}^{-3}$ over the entire altitude region, superposed with a few structures.

- Two peaks are seen, one at $750 \mathrm{~m}$ and the other around $2000 \mathrm{~m}$, where the values of $M_{B}$ are significantly higher.

The above observations are of immense importance in aerosol characterization and radiative forcing estimation as they show significantly large amounts of absorbing aerosols present throughout the lower atmosphere and it is well-established that the radiative forcing of $\mathrm{BC}$ increases when it is located at higher altitudes, over-reflecting land surfaces or scattering clouds (Haywood and Ramaswamy 1998). Occurrence of substantial amounts of BC particles would lead to cloud burnoff (Ackerman et al 2000) and modify the properties of cloud condensation nuclei (Lohmann et al $2000)$. In this context, the steady and large value of $M_{B}$ up to $3 \mathrm{~km}$ assumes great importance. The occurrence of the peaks has direct bearing on the ABL dynamics. A comparison of the profile in figure 13 with that of the potential temperature in figure 12 (blue curve) around the same location (but for another day) shows very clearly that the peaks in $M_{B}$ are associated with the inversions in the potential temperature occurring at $800 \mathrm{~m}$ and $2000 \mathrm{~m}$.

Using collated measurements of the total mass concentrations made onboard the same aircraft 
sortie using the optical particle counter (Grimm) in the mass mode, the $\mathrm{BC}$ mass fraction $\left(F_{B C}\right)$ to the total aerosol mass was estimated for each measurement and altitude profile of $F_{B C}$ is shown in the right panel of figure 13. For surface level, the shipboard data were used. This profile, obtained for the first time over any Indian location has very serious implications, as the $\mathrm{BC}$ fraction to the total increases from $<5 \%$ at surface to as much as $8 \%$ at the top of the mixed layer. Beyond this altitude, even though $F_{B C}$ decreases, it is still above the surface level value even at $2000 \mathrm{~m}$. Based on model calculations, Babu and Moorthy (2004) have shown that the direct short wave forcing due to aerosol depends strongly on $F_{B C}$ (rather than on $M_{B}$ ). As such, using the surface values of $F_{B C}$ would lead to an underestimate of the radiative forcing.

\subsection{Altitude profile of ozone over BoB, off Bhubaneswar}

Regular ozonesondes with GPS sondes were launched on alternate days from the ship for investigating the spatial variation of the altitude variation of ozone, total column ozone, as well as the tropospheric ozone. One typical profile, again obtained off Bhubaneswar on 20 March, 2006 is shown in figure 14. The high-resolution profile shows a constant mixing ratio of $\sim 70 \mathrm{ppbv}$ in the lower atmosphere and several structures above. The stratospheric peak ( $\sim 10$ ppmv $)$ occurs at an altitude of $\sim 29 \mathrm{~km}$.

\section{Conclusions}

A multi-institutional, multi-platform, and multiinstrumental campaign spanning over two months to characterize the aerosol environment over and around India, using a wide network of aerosol observatories covering the mainland and vast expanses of the Arabian Sea and BoB, supplemented with extensive aircraft profiling from coastal regions, was carried out for the first time. The preliminary results show large spatio-temporal heterogeneity in almost all aerosol parameters. Long-range transport from west Asia, through northwest India and associated elevated aerosol layers, well above the boundary layer, contribute strongly to the temporal changes in the spatial distribution of aerosols as well as in their impact at locations far off from the mainland. The dynamics of the atmospheric boundary layer leads to structures in the vertical profile of species. The main findings, though of preliminary nature are:

- Low aerosol optical depths (AOD) over most part of the Arabian Sea, except two pockets; one off Mangalore and the other, less intense, in the central Arabian Sea at $\sim 18^{\circ} \mathrm{N}$ latitude.

- High Ångström exponent in the southern Arabian Sea signifying steep AOD spectra and higher abundance of accumulation mode particles in the southern Arabian Sea and off Mangalore, where the columnar loading is generally low.

- Remarkably low exponents signifying increased concentration of coarse mode aerosols and high columnar abundance in the northern Arabian Sea.

- Compared to the AS, AODs were generally high over the BoB and depicted well-defined latitudinal variations, with the AODs increasing from south to north.

- A region, having a spatial extent of $\sim 3^{\circ} \times 3^{\circ}$, with high to very high AOD was seen in the mid-ocean of Head-BoB. This 'detached high' was apparently isolated form the mainland. It is attributed to the combined effects of longrange transport of aerosols form the western continents and a spatial confinement over the oceanic region by the prevailing low-level anticyclone.

- In contrast to the scenario over the oceans, AODs and their spectral dependencies depicted significant spatial and temporal heterogeneity over the mainland. While in the southern peninsula, AODs increased sharply from moderate values in March to peak values in April and decreases in May, in the north Indian regions, there was a consistent increase in AOD from March to May. The northeastern station Dibrugarh, which was somewhat shielded by the surrounding Himalayan ranges, was the only exception.

- The Ångström exponents, derived from the AOD spectra, showed enhanced coarse mode loading in the north Indian regions, compared to the southern India. Moreover, as the months progressed from March to May, the dominance of coarse mode aerosols increased in the size spectrum over entire Indian mainland, still maintaining the regional distinctiveness. Enhanced long-range transport of aerosols from west Asia and northwest India, contributed significantly to the enhancement of AODs and the lowering of the Angström exponents; if it is the peninsular regions that are more impacted in April, the north Indian regions were most affected during May.

- Altitude profiles from aircraft showed a steady $\mathrm{BC}\left(1.4 \mu \mathrm{g} \mathrm{m}^{-3}\right)$ level up to $3 \mathrm{~km}$ altitude superposed with structures, which were associated with the inversions in the atmospheric boundary layer (ABL) as revealed by the potential temperature profiles. 
- A remarkable increase with altitude of the $\mathrm{BC}$ mass fraction, implying higher abundance of BC and increased forcing.

- Presence of convectively mixed layer extending up to about $1 \mathrm{~km}$ over the Arabian Sea and Bay of Bengal.

- The offshore extent of anthropogenic impact at the port and urban centres are limited to $<100 \mathrm{~km}$ at the surface level.

- Long-range transport of aerosols, through airmass trajectories, from west Asia and NW arid regions of India leading to formation of elevated aerosol layers extending as far as $400 \mathrm{~km}$ off the east coast.

\section{Acknowledgements}

The ICARB was a national endeavour. More than 100 scientists from 26 institutions including national laboratories, academic institutions, and universities, contributed to its success and we are thankful to each one of them. Though it would be difficult to list them by name, the research outputs from these investigators appear as scientific papers in the same issue. We are grateful to the Director, NRSA and its aircraft team headed by Dr. K Kalyanaraman, and V Raghu Venkataraman for the total co-operation and the immense help. Excellent support and facilities were provided by the National Centre for Antarctic and Ocean Studies, which provided the research vessel for a period of two months dedicated for this campaign and we are extremely thankful to Dr. Rasik Ravindra, and Dr. M Sudhakar and his team. The ICARB campaign was an outcome of the untiring efforts of the Geosphere Biosphere Programme of the Indian Space Research Organization and we are thankful to Dr. V Jayaraman, Prof. R Sridharan, and Dr. K Parameswaran for all the encouragement and support. The technical support provided by Mr. P Pradeep Kumar and Mr. P Pramod in installing the instruments onboard the ship and making measurements is acknowledged. The support provided by the India Meteorological Department in making the regular meteorological measurements as well as balloon ascents from the ship was creditable.

\section{References}

Ackerman A S, Toon O B, Stevens D E, Heymsfield A J, Ramanathan V and Welton E J 2000 Reduction of tropical cloudiness by soot; Science 288 1042-1047.

Alexandrov M D, Lacis A A, Carlson B E and Cairns B 2002 Remote sensing of atmospheric aerosols and trace gases by means of multifilter rotating shadowband radiometer. Part II: Climatological applications; J. Atmos. Sci. 59 $544-566$
Anderson T L et al 1996 Performance characteristics of a high sensitivity, three-wavelength, total scatter/ backscatter nephelometer; J. Atmos. Oceanic Technol. 13 967-985.

Ångström A 1964 The parameters of atmospheric turbidity; Tellus 16 64-75.

Babu S S and Moorthy K K 2002 Aerosol black carbon over a tropical coastal station in India; Geophys. Res Lett. 29(23) 2098, 13-1 to 13-4, doi: 10.1029/2002GL015662.

Babu S S, Satheesh S K and Moorthy K K 2002 Aerosol radiative forcing due to enhanced black carbon at an urban site in India; Geophys. Res. Lett. 29(18) 10.1029/2002GL015179.

Babu S S, Moorthy K K and Satheesh S K 2004 Aerosol black carbon over Arabian Sea during inter monsoon and summer monsoon seasons; Geophys. Res. Lett. 31(6) L06104, 10.1029/2003GL018716.

Bates T S, Huebert B J, Gras J L, Griffiths F B and Durkee P A 1998 International Global Atmospheric Chemistry (IGAC) project's first aerosol experiment (ACE 1): Overview; J. Geophys. Res. 103 16,297-16,318.

Bates T S et al 2001 Regional physical and chemical properties of the marine boundary layer aerosol across the Atlantic during Aerosols99: An overview; J. Geophys. Res. 106 20,767-20,782.

Beegum S N, Moorthy K K, Nair V S, Babu S S, Satheesh S K, Vinoj V, Ramakrishna Reddy R, Rama Gopal K, Badarinath K V S, Niranjan K, Santosh Kumar Pandey, Behera M, Jeyaram A, Bhuyan P K, Gogoi M M, Sacchidanand Singh, Pant P, Dumka U C, Yogesh Kant, Kuniyal J C and Darshan Singh 2008 Characteristics of Spectral Aerosol Optical Depths over India during ICARB; J. Earth Sys. Sci. (this issue).

Charlson R J, Schwartz S E, Hales J M, Cess R D, Coakley J A, Hansen J E and Hofmann D J 1992 Climate forcing by anthropogenic aerosols; Science $\mathbf{2 5 5}$ 423-430.

Crescenti G H 1997 A lookback on two decades of Doppler sodar comparison studies; Bull. Amer. Meteor. Soc. $\mathbf{7 8}$ 651-673.

Diner D J, Ackerman $\mathrm{T}$ P, Anderson $\mathrm{T}$ L et al 2004 Progressive Aerosol Retrievel and Assimilation Global Observing Network (PARAGON): An integrated approach for characterizing aerosol climatic and environmental interactions; Bull. Amer. Meteor. Soc. 85(10) $1491-1501$.

Fishman J et al 1996 NASA GTE TRACE A experiment (September-October 2002): Overview; J. Geophys. Res. $10123,865-23,880$

Ganguly D, Gadhavi H, Jayaraman A, Rajesh T A and Misra A 2005 Single scattering albedo of aerosols over the central India: Implications for the regional aerosol radiative forcing; Geophys. Res. Lett. 32 LI8803, doi:10.1029/2005GL023903.

Hansen A D A, Rosen H and Novakov T 1984 Aethalometer - An instrument for the real-time measurement of optical absorption by aerosol particles; Sci. Total Environ. 36 191-196.

Haywood J M and Ramaswamy V 1998 Global sensitivity studies of the direct radiative forcing due to anthropogenic sulfate and black carbon aerosols; J. Geophys. Res. 103 6043-6058.

Holben B N, Eck T F, Slutsker I, Tanré D, Buis J P, Setzer A, Vermote E, Reagan J A, Kaufman Y J, Nakajima T, Lavenu F, Jankowiak I and Smirnov A 1998 AERONET - A federated instrument network and data archive for aerosol characterization; Rem. Sens. Environ. 66 1-16.

Huebert B J, Bates T, Russell P B, Shi G, Kim Y J, Kawamura K, Carmichael G and Nakajima T 2003 
An overview of ACE-Asia: Strategies for quantifying the relationships between Asian aerosols and their climatic impacts; J. Geophys. Res. 108 doi:10.1029/ 2003JD003550.

IPCC 2007 Climate Change 2007: The Physical Science Basis. Contribution of Working Group I to the Fourth Assessment Report of the Intergovernmental Panel on Climate Change; Cambridge University Press: Cambridge, United Kingdom and New York.

Jacob D J, Crawford J H, Kleb M M et al 2003 The transport and chemical evolution of over the Pacific (TRACE-P) aircraft mission: design, execution, and first results; J. Geophys. Res. 108 9000, doi:10.1029/2002JD003276.

Kamra A K, Murugavel P, Pawar S D and Gopalakrishnan V 2001 Background aerosol concentration derived from the atmospheric electric conductivity measurements made over the Indian ocean during INDOEX; J. Geophys. Res. 106 28,463-28,651.

Kaufman Y J, Hobbs P V, Kirchhoff V W J H, Artaxo P, Remer L A, Holben B N, King M D, Ward D E, Prins E M, Longo K M, Mattos L F, Nobre C A, Spinhirne J D, Ji Q, Thompson A M, Gleason J F, Christopher S A and Tsay S C 1998 Smoke, Clouds, and Radiation - Brazil (SCAR_B) experiment; J. Geophys. Res. 103 31,783-31,808.

Kaufman Y J, Setzer A and Ward D et al 1992 Biomass burning Airborne and Spaceborne Experiment in the Amazonas (BASE-A); J. Geophys. Res. 97 $14,581-14,599$.

Kaufman Y J, Tanre D and Boucher O 2002 A satellite view of aerosols in the climate system; Nature $\mathbf{4 1 9}$ 215-223.

King M D, Platnick S, Moeller C C, Revercomb H E and Chu D A 2003 Remote sensing of smoke, land, and clouds from the NASA ER-2 during SAFARI2000; J. Geophys. Res. 108(D13) 8502, doi:10.1029/2002JD003207.

Lelieveld J, Berresheim H and Borrmann S et al 2002 Global air pollution crossroads over the Mediterranean; Science $298794-799$.

Lindesay J A, Andreae M O and Goldammer J G et al 1996 International Geosphere Biosphere Programme/International global Atmospheric Chemistry SAFARI-92 field experiment: Background and overview; J. Geophys. Res. $10123,521-23,530$.

Lohmann U, Feichter J, Penner J and Leatch R 2000 Indirect effect of sulfate and carbonaceous aerosols: A mechanistic treatment; J. Geophys. Res. 105 $12,193-12,206$.

Matthias V and Coauthors 2004 Aerosol lidar intercomparison in the framework of EARLINET, Part I: Instruments; Appl. Opt. 43 961-976.

McCormick R A and Ludwig J H 1967 Climate modification by atmospheric aerosols; Science 156 (3780), 1358-1359.

Moorthy K K, Babu S S and Satheesh S K 2003 Aerosol spectral optical depths over the Bay of Bengal: Role of transport; Geophys. Res. Lett. 30(5) doi:10.1029/ 2002GL016520.

Moorthy K K, Babu S S and Satheesh S K 2005a Aerosol characteristics and Radiative Impacts over the Arabian Sea during the Intermonsoon Season: Results from ARMEX Field Campaign; J. Atmos. Sci. 62 192-206.

Moorthy K K et al 2005b Wintertime spatial characteristics of boundary layer aerosols over peninsular India; J. Geophys. Res. 110 D08207, doi:10.1029/2004JD005520.

Moorthy K K, Babu S S and Satheesh S K 2007 Temporal heterogeneity in aerosol characteristics and the resulting radiative impact at a tropical coastal station-I:
Microphysical and Optical properties; Ann. Geophys. 25 2293-2308.

Moorthy K K, Babu S S, Sunilkumar S V, Gupta P K and Gera B S 2004 Altitude profiles of aerosol BC, derived from aircraft measurements over an inland urban location in India; Geophys. Res. Lett. 31 L22103, doi:10.1029/2004gl021336.

Moorthy K K, Niranjan K, Narasimhamurthy B, Agashe V V and Murthy B V K 1999 Aerosol Climatology over India, 1 . ISRO GBP MWR Network and Database, Scientific Report; ISRO GBP, SR 03 99, Indian Space Research Organisation, India.

Moorthy K K and Saha A 2000 Aerosol study during INDOEX: Observation of enhanced aerosol activity over the mid Arabian Sea during the northern winter; J. Atmos. Sol. Terr. Phys. 62 65-72.

Moorthy K K and Satheesh S K 2000 Characteristics of aerosols over a remote island, Minicoy in the Arabian Sea: Optical properties and retrieved size characteristics; Quart. J. Roy. Meteor. Soc. 126 81-109.

Morys M, Mims III F M, Hagerup S, Anderson S E, Baker A, Kia J and Walkup T 2001 Design, calibration and performance of Microtops II handheld ozone monitor and sunphotometer; J. Geophys. Res. 106 14,573-14,582.

Nair V S, Moorthy K K, Alappattu D P, Kunhikrishnan P K, George S, Nair P, Babu S S, Abish B, Satheesh S K, Tripathi S N, Niranjan K, Madhavan B L, Srikanth V, Dutt C B S, Badrinath K V S and Ramakrishna Reddy R 2007 Wintertime aerosol characteristics over the Indo-Gangetic Plain (IGP): Impacts of local boundary layer processes and longrange transport; J. Geophys. Res. 112 D13205, doi: 10.1029/2006JD008099.

Nair V S, Moorthy K K, Babu S S, Narasimhulu K, Reddy L S S, Reddy R R, Rama Gopal K, Sreekanth V, Madhavan B L and Niranjan K 2008 Size segregated aerosol mass concentration measurements over the Arabian Sea during ICARB; J. Earth. Sys. Sci. (this issue).

Nair S K, Parameswaran K and Rajeev K 2005 Seven-years satellite observations of the mean structure and variabilities in the regional aerosol distribution over the oceanic areas around the Indian subcontinent; Ann. Geophys. 23 2011-2030

Naja et al 1999 Variabilities in $\mathrm{O}_{3}$, NO, CO and $\mathrm{CH}_{4}$ over the Indian Ocean during winter; Curr. Sci. $\mathbf{7 6}$ 931-937.

Niranjan K, Sreekanth V, Madhavan B L and Moorthy K K 2007 Aerosol physical properties and Radiative forcing at the outflow region from the Indo-Gangetic Plains during typical clear and hazy periods of wintertime; Geophys. Res. Lett. 34 L19805, doi: 10.1029/2007GL031224.

Pant P, Hegde P, Dumka U C, Sagar R, Satheesh S K, Moorthy K K, Saha A and Srivastava M K 2006 Aerosol Characteristics at a High Altitude Location in Central Himalayas: Optical Properties and Radiative Forcing; J. Geophys. Res. 111(D17) D17206, 10.1029/2005JD006768.

Parameswaran K, Nair P R, Rajan R and Ramana M V 1999 Aerosol loading in coastal and marine environments in the Indian Ocean region during winter season; Curr. Sci. 76 947-955.

Penner J E, Charlson R J, Hales J M, Laulainen N S, Leifer R, Novakov T, Ogren J, Radke L F, Schwartz S E and Travis L 1994 Quantifying and minimizing uncertainty of climate forcing by anthropogenic aerosols; Bull. Am. Meteorol. Soc. 75 375-400.

Pillai P S and Moorthy K K 2001 Aerosol mass-size distributions at a tropical coastal environment: Response to 
mesoscale and synoptic scale processes; Atmos. Environ. 35 4099-4122.

Quinn P K and Bates T S 2005 Regional aerosol properties: Comparisons of boundary layer measurements from ACE 1, ACE 2, Aerosols99, INDOEX, ACE Asia, TARFOX, and NEAQS; J. Geophys. Res. 110 D14202, doi: 10.1029/2004JD004755.

Raes F, Bates T, McGovern F M and van Liederkerte M 2000 The second Aerosol Characterization Experiment (ACE-2): General overview and main results; Tellus 52B $111-126$

Rajeev K, Ramanathan V and Meywerk J 2000 Regional aerosol distribution and its long-range transport over the Indian Ocean; J. Geophys. Res. 105 2029-2043.

Ramachandran S 2004 Spectral aerosol optical characteristics during the north east monsoon over the Arabian Sea and the tropical Indian Ocean: Aerosol optical depths and their variabilities; J. Geophys. Res. 109 D19207, doi:10.1029/2003JD004476.

Ramanathan V et al 2001 Indian Ocean Experiment: An integrated analysis of the climate and the great IndoAsian haze; J. Geophys. Res. 106 28,371-28,398.

Remer L A, Gasso S, Hegg D A, Kaufman Y J and Holben B N 1997 Urban/industrial aerosol: Groundbased Sun/sky radiometer and airborne in situ measurements; J. Geophys. Res. 102 16,849-16,859.

Russell P B, Hobbs P V and Stowe L L 1999 Aerosol properties and radiative effects in the United States East Coast haze plume: An overview of Tropospheric Aerosol Radiative Forcing Observational Experiment (TARFOX); J. Geophys. Res. 104 2213-2222.

Satheesh S K, Ramanathan V, Jones X L, Lobert J M, Podogorny I A, Prospero J M, Holben B N and Leob N G 1999 A Model for the natural and anthropogenic aerosols for the tropical Indian Ocean derived from Indian Ocean Experiment data; J. Geophys. Res. 104(D22) 27421-27440.
Satheesh S K, Vinoj V and Moorthy K K 2006 Vertical distribution of aerosols over a continetal urban site in India; Geophys. Res. Lett. 33 L20816, doi:10.1029/ 2006/GL027729.

Smith Jr W L, Charlock T P, Kahn R, Martins J V, Remer L A, Hobbs P V, Redemann J and Rutledge C K 2005 EOS Terra Aerosol and Radiative Flux Validation: An Overview of the Chesapeake Lighthouse and Aircraft Measurements for Satellites (CLAMS) Experiment; J. Atmos. Sci. 62(4) 903-918.

Tripathi S N, Dey S, Tare V and Satheesh S K 2005 Aerosol black carbon radiative forcing at an industrial city in northern India; Geophys. Res. Lett. 32 doi:10.1029/ 2005/GL022515.

Twomey S 1977 Atmospheric aerosols; Elsevier, Amsterdam-Oxford-New York.

Vinoj V, Babu S S, Satheesh S K, Moorthy K K and Kaufman Y J 2004 Radiative forcing by aerosols over the Bay of Bengal region derived from ship borne, islandbased and satellite (Moderate-Resolution Imaging Spectroradiometer) observations; J. Geophys. Res. 109(D5) D05203, doi: 10.1029/2003JD004329.

Vinoj V and Satheesh S K 2003 Measurements of aerosol optical depth over Arabian Sea during summer monsoon season; Geophys. Res. Lett. 30 doi:10.1029/ 2002 GL0166.

Wolfe D E and Gutman S I 2000 Developing on operational, surface based, GPS water vapour observing system for NOAA: network design and results; J. Atmos. Oceanic. Technol. 17 426-440.

Yu H, Kaufman Y J, Chin M, Feingold G, Remer L A, Anderson T L, Balkanski Y, Bellouin N, Boucher O, Christopher S, DeCola P, Kahn R, Koch D, Loeb N, Reddy M S, Schulz M, Takemura T and Zhou M 2006 A review of measurement-based assessments of the aerosol direct radiative effect and forcing; Atmos. Chem. Phys. 6 613-666. 